Dr. Patawari, S.HI., M.H.

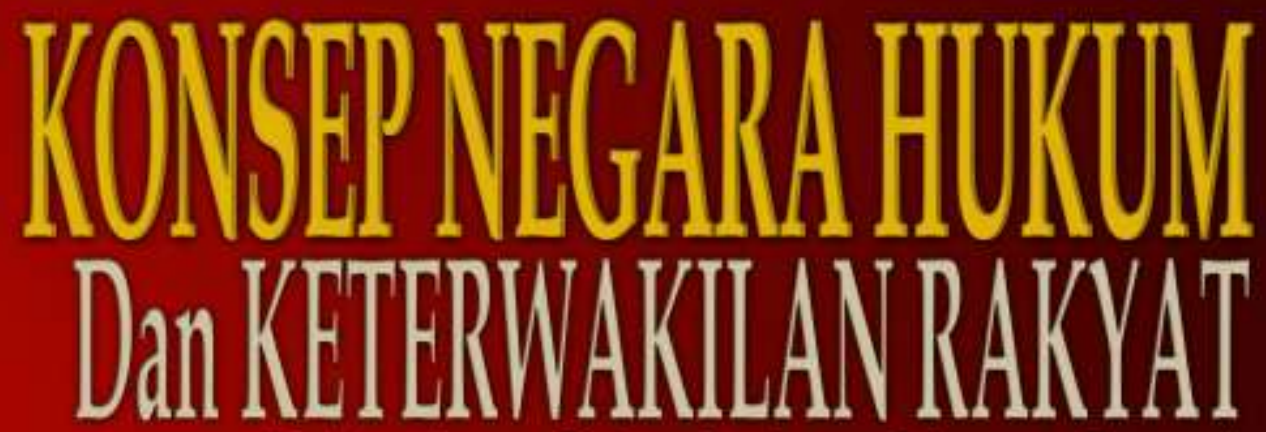

(Perbandingan Sistem Parlemen Beberapa Negara)

Kata Pengantar:

Dr. Hamdan Zoelva, S.H., M.H. 


\section{KONSEP NEGARA HUKUM DAN KETERWAKILAN RAKYAT (Perbandingan Sistem Parlemen Beberapa Negara)}

$\begin{array}{ll}\text { Penulis } & \text { : Dr. Patawari, S.HI., M.H. } \\ \text { Editor } & \text { : Ahsan Yunus, S.H., M.H. }\end{array}$

Perpustakaan Nasional: Katalog Dalam Terbitan (KDT)

Konsep Negara Hukum dan Keterwakilan Rakyat (Perbandingan Sistem Parlemen Beberapa Negara)

ISBN: 978-602-1638-10-1

All Right Reserved
Hak Cipta Dilindungi Undang-Undang

Penerbit:

Distributor: 


\section{DAFTAR ISI}

Halaman Judul

Halam Penerbit

i

Daftar Isi

ii

Daftar Tabel

Ucapan Terima Kasih

iii

Prakata vi

Kata Pengantar

BAB I KONSEP NEGARA HUKUM
A. Konsep Rechtstaat
B. The Rule of Law
C. Konsep Socialist Legality
D. Konsep Nomokrasi Islam
E. Konsep Negara Hukum Pancasila (Indonesia)
5
7
8
9

vii

xii

1

BAB II KONSEP KEDAULATAN RAKYAT \& DEMOKRASI

A. Pengertian Kedaulatan Rakyat 17

B. Kedaulatan Rakyat dan Ketentuan Hukum 19

C. Konsep dan Indikator Demokrasi 21

D. Kedaulatan Rakyat dalam UUD NRI 1945

BAB III KONSEP KETERWAKILAN RAKYAT 31

A. Pengertian Perwakilan Rakyat 31

B. Bentuk Perwakilan Rakyat 33

C. Bentuk Perwakilan Representatif 36

D. Perwakilan fungsional 39

BAB IV PARTAI POLITIK

A. Pengertian Partai Politik 42

B. Fungsi Rekrutmen Partai Politik 44

BAB V REKRUTMEN ANGGOTA PARLEMEN DI BEBERAPA

NEGARA

A. Konsep Rekrutmen Anggota Parlemen 47

B. Rekrutmen Anggota Parlemen Di Beberapa Negara $\quad 55$

1. Negara Democratic Republic Chile (Congreso Nacional) 56

2. Negara Republik Islam Iran (The Islamic Consultative Assembly) 57

3. Negara Federative Republic of Brazil (Camara dos Deputados) 58

4. Negara German Federal Republic's (Deutscher Bundestag) 59

5. Negara Democratic Republic Itali (Chamber of Deputies) 59

6. Negara Democratic Regime of Government Thailand (The National Legislative Assembly) 60

7. Negara United States of America's (House of Representatives) 
8. Negara Republic of Singapore (The Legislature May) 62

9. Negara Republik Indonesia (Dewan Perwakilan Rakyat) 64

BAB VI MEKANISME REKRUTMEN ANGGOTA PARLEMEN DI BEBERAPA NEGARA

A. Ketentuan Mekanisme rekrutmen calon anggota Dewan Perwakilan Rakyat Di indonesia

B. Rekrutmen calon anggota Dewan Perwakilan Rakyat berdasarkan AD/ART Partai Politik

C. Syarat Anggota Parlemen dibeberapa negara

D. Kompetensi Calon Anggota Parlemen Dibeberapa Negara

BAB VII STANDAR PEMILU INTERNASIONAL

83

A. Pengertian Pemilihan Umum

B. Sistem Pemilihan Umum

97

C. Standar Hukum Penyelenggara Pemilihan Umum Internasional 99

D. Pemilihan Umum Dewan Perwakilan Rakyat di Indonesia

BAB VIII PENATAAN HUKUM PEMILU PARLEMEN DI BEBERAPA NEGARA

A. Profesionalitas Penyelenggara Pemilihan Umum

B. Penyelenggara pemilihan umum di beberapa Negara

C. Integritas penyelenggara pemilihan umum di beberapa Negara

D. Akuntabilitas penyelenggara pemilihan umum

1. Akuntabilitas hukum

138

2. Akuntabilitas publik

BAB IX KONSEP PENGAWASAN TERHADAP ANGGOTA PARLEMEN

A. Konsep Pengawasan Anggota Parlemen 141

1. Pengertian Pengawasan 141

2. Bentuk Pengawasan 145

3. Pengawasan Kinerja 146

B. Praktik Pengawasan Terhadap Parlemen Di Beberapa

Negara

1. Sistem Pengawasan Terhadap Anggota parlemen di beberapa negara

2. Ketentuan pengawasan terhadap anggota Parlemen di beberapa negara

3. Bentuk Pengawasan Terahadap anggota Parlemen Di beberapa Negara 


\section{DAFTAR TABEL}

Tabel I

66

Mekanisme Rekrutmen Calon Anggota Perlemen di Beberapa Negara

Tabel II

Mekanisme Rekrutmen Calon Anggota Dpr Berdasarkan AD/ART

Partai Politik

\section{Tabel III}

Ketentuan Syarat Rekrutmen Calon Anggota Parlemen di Beberapa Negara

\section{Tabel IV}

Kompetensi Calon Anggota Parlemen di Beberapa Negara

\section{Tabel V}

Penguatan Kompetensi Calon Anggota DPR oleh Partai Politik

\section{Tabel VI}

Mekanisme Rekrutmen Penyelenggara Pemilihan Umum di Beberapa Negara

\section{Tabel VII}

Integritas Penyelenggara Pemilihan Umum di Beberapa Negara

\section{Tabel VIII}

Ketentuan Pengawasan Terhadap Anggota Parlemen di Beberapa Negara

\section{Tabel IX}

Ketentuan Pengawasan Terhadap Anggota Parlemen di Beberapa Negara 


\section{UCAPAN TERIMA KASIH}

$\mathrm{P}$ uji syukur kehadirat Allah Subehana Wata'ala. Atas Segala Rahmat, Hidayah, dan Taufik-Nya, salawat dan salam kepada Nabiullah Muhammad SAW. yang penulis jadikan sebagai tauladan untuk terinspirasi mengembangkan ilmu pengetahuan yang tak lain tak bukan adalah untuk ibadah lillahi Ta'ala. Sehingga penulis menyelesaikan buku yang berjudul "Konsep Negara Hukum dan Keterwakilan Rakyat (Perbandingan Sistem Parlemen Beberapa Negara)."

Buku yang menguraikan terkait bagaimana lahirnya anggota Parlemen yang aspiratif, dengan menggunakan kajian mulai dari mekanisme rekrutmen anggota Partai Politik, Penyelenggaraan Pemilihan umum, hingga pengawasan terhadap anggota parlemen dengan melakukan perbandingan hukum beberapa negara. Tulisan ini diharapkan dapat bermanfaat bagi kalangan akademisi baik dibidang hukum maupun dalam bidang politik, dan pemerintahan. Demikian pada praktisi hukum, politik, dan profesional.

Buku ini terbit tidak lepas dari pada bantuan dan dorongan dari beberapa kalangan. Olehnya itu, penulis berterima kasih dan penghargaan setinggi tingginya kepada Orang Tua/Mertua (Hj.Pani (Alm.), dan H. Abd Rahim / Hj. Madina dan Samarang) dan Istri (Rasnawati, S.SI c.M.EI) dan anak (Misbahul Khair Patawari, Miftahul khair Patawari), atas dorongan dalam menyelesaikan buku ini. Terima kasih atas bimbingan Kakanda Dr.Hamdan Zoelva, SH.MH, Kakanda Prof. Dr. Andi Pangerang Moentha, SH.MH. DFM. Kepada teman teman yang senantiasa memberikan masukan dan koreksi H.Asba Hamid, SH.MH. Ahsan Yunus, SH.MH, Ridho, Saudaraku Ahmad Mustari, terkhusus Krg.Bintoeng atas inspirasinya. Dan kawan lainnya yang tidak dapat saya sebutkan satu persatu.

Walau buku ini merupakan saripati dari disertasi yang telah dipresentasikan didepan para Guru Besar Hukum UNHAS saat promosi Doktor Ilmu Hukum UNHAS Tahun 2015, penulis menyadari pelbagai kekurangan, dan kehilafan dalam penulisan. Sehingga, penulis berterima kasih pada pembaca, yang memberikan kritik konstruktif. ... dan hanya itu.

Makassar, 16 Maret 2017

Penulis

Dr. Patawari, S.HI., M.H. 


\section{PRAKATA}

linea ke-empat Pembukaan Undang Undang Dasar Negara Republik
Indonesia Tahun 1945 (UUD NRI 1945) bahwa: "Kemudian dari pada itu
untuk membentuk suatu Pemerintah Negara Indonesia yang melindungi segenap bangsa Indonesia dan seluruh tumpah darah Indonesia dan untuk memajukan kesejahteraan umum, mencerdaskan kehidupan bangsa, dan ikut melaksanakan ketertiban dunia yang berdasarkan kemerdekaan, perdamaian abadi dan keadilan sosial, maka disusunlah Kemerdekaan Kebangsaan Indonesia itu dalam suatu Undang Undang Dasar Negara Indonesia yang terbentuk dalam suatu susunan Negara Republik Indonesia yang berkedaulatan rakyat dengan berdasa kepada Ketuhanan Yang Maha Esa, Kemanusiaan yang adil dan beradab, Persatuan Indonesia, Kerakyatan yang dipimpin oleh hikmat kebijaksanaan dalam permusyawaratan/perwakilan, serta dengan mewujudkan Keadilan sosial bagi seluruh rakyat Indonesia."

Manifestasi alinea ke-empat Pembukaan, sebagaimana Pasal 1 Ayat (2) UUD NRI 1945 bahwa "Kedaulatan berada ditangan rakyat dan dilaksanakan menurut Undang-Undang Dasar". Kedaulatan rakyat, dijamin oleh Undang Undang Dasar bahwa rakyatlah yang sesungguhnya pemilik negara dengan segala kewenangannya untuk menjalankan semua fungsi kekuasaan negara, baik dibidang legislatif, eksekutif, maupun yudikatif, dengan berdasar pada "Ketuhanan Yang Maha Esa".

Kebijakan pemerintahan berdasarkan pada kehendak dan keinginan rakyat, maka rakyat yang menentukan arah dan kebijakan negara, dan rakyat memiliki kekuasaan sepenuhnya di dalam menjalakan roda pemerintahan. Maka, peraturan dan segala kebijakan pemerintahan seharusnya melindungi dan mengatur segala hak konstitusional rakyat. Perwujudan perwakilan rakyat melalui bentuk demokrasi yang berarti from the people (dari rakyat), by the people (oleh rakyat), dan for the people (untuk rakyat) mengandung makna bahwa rakyat berdaulat atas penentuan arah pengelolaan negara dan jalannya roda pemerintahan. Olehnya itu, harus sesuai dengan kehendak dan keinginan dari masyarakat sebagai pemegang kedaulatan tertinggi.

Keterlibatan rakyat dalam pengelolaan dan pengambilan keputusan pemerintahan menjadi indikator kedaulatan rakyat, namun tidak dimaksudkan bahwa seluruh rakyat harus terlibat secara langsung. Untuk itu, diperlukan adanya lembaga perwakilan rakyat yang bertugas untuk menerima dan menyalurkan aspirasi masyarakat; merumuskan peraturan sebagai pijakan di dalam pengelolaan pemerintahan; dan melakukan budgeting sesuai dengan kehendak dan kebutuhan masyarakat.

Pelaksanaan kedaulatan rakyat, dalam negara Indonesia mengharuskan adanya partai politik yang melaksanakan fungsi rekrutmen politik, sosialisasi 
poltik, sarana pencerdasan dan atau pembentukan karakter dan perilaku pemilih. Partai politik berperan penting di dalam melaksanakan demokrasi sesuai dengan kehendak dan keinginan masyarakat secara umum, berdasarkan ketentuan perundang undangan, konsekuensi sebagai negara hukum.

Peranan partai politik sangat penting dalam menyiapkan anggota yang memiliki integritas dan kompetensi untuk melaksanakan tugas-tugas perwakilan rakyat. Hal ini dilakukan agar tercipta kesinambungan antara keinginan rakyat dan kebijakan yang dikeluarkan oleh wakil rakyat. Untuk itu, diperlukan adanya aturan pelaksanaan tugas lembaga politik yang dituangkan dalam peraturan perundang undangan untuk perwakilan rakyat yang memiliki integritas, kompetensi professional sebagai menjadi wakil rakyat.

Penguatan peran dan fungsi partai politik sebelum pelaksanaan pemilihan umum legislatif harus menyangkut pada pembangunan pemikiran anggotanya untuk memahami dan menyadari peran dan fungsinya sebagai calon anggota DPR. Sedangkan, pada pelaksanaan pemilihan umum partai politik berperan dan bertugas untuk menyosialisasikan anggotanya kepada konstituen agar calon yang diusulkan dapat dipahami kapabilitas dan integritasnya.

Peran dan tanggungjawab partai politik tidak hanya menyediakan anggotanya pada pemilihan umum hingga terpilih menjadi anggota DPR. Namun, partai politik tetap mengontrol kinerja dari anggota partai politik yang duduk mewakili rakyat (konstituen), sehingga kinerja para anggota partai poltik tidak keluar dari koridor tujuan partai politik.

Pengisian lembaga DPR dewasa ini melalui mekanisme pemilihan umum, sedangkan peserta pemilihan umum adalah partai politik. Keterlibatan partai politik dalam lembaga perwakilan rakyat (DPR) seharusnya memberi ruang kepada masyarakat untuk mengisi lembaga perwakilan tersebut, sesuai dengan ketentuan hukum.

Pemilihan umum anggota Dewan Perwakilan Rakyat diharapkan mewujudkan perwakilan rakyat yang aspiratif, yakni mampu menampung dan menyalurkan keinginan masyarakat. Anggota DPR adalah mereka yang berasal dari masyarakat atau warganegara Indonesia yang memahami persoalan dan keinginan masyarakat berdasarkan daerah yang diwakilinya.

Parameter calon anggota dewan yang aspiratif, paling tidak adalah Pertama, anggota yang mengikuti tahapan seleksi calon anggota di partai politik dengan mekanisme, syarat serta adanya proses penguatan calon yang dilakuakn oleh partai politik peserta pemilihan umum. Kedua, adanya penyelenggara pemilihan umum yang professional, akuntabilitas, dan Ketiga anggota DPR yang terpilih melalui mekanisme dengan syarat dan ketentuan yang diatur, maka anggota DPR harus diawasi oleh suatu lembaga tertentu, baik kinerja, etika selama menjadi anggota DPR. bentuk pengawasannya baik secara preventif maupun secara represif.

Undang undang penyelenggaraan pemilihan umum menghendaki adanya pemilihan umum yang dikelola secara profesional dan transparan, guna 
mewujudkan pemilihan umum yang berkualitas dalam sistem pemerintahan demokratis penyelenggara pemilihan umum dalam hal ini Komisi Pemilihan Umum (KPU) yang bersifat independen, memiliki integritas, kapabilitas, akuntabilitas dan tidak terkooptasi dengan kepentingan politik tertentu.

Selain itu, persoalan keterwakilan rakyat yang aspiratif turut memengaruhi kualitas pemilihan umum. Hal ini diwujudkan melalui penguatan kelembagaan serta peningkatan fungsi dan peran partai politik dengan pelibatan masyarakat, hingga pada proses pencalonan legislative (perlemen). Kedaulatan rakyat menghendaki adanya demokrasi, maka pelaksanaan keterwakilan rakyat melalui mekanisme seleksi oleh partai politik. Tanggungjawab partai politik adalah dalam melaksanakan rekrutmen dan menentukan syarat menjadi bakal calon anggota DPR dan melakukan penguatan peran dan fungsi partai politik.

Tidak sedikit masyarakat meninggalkan dan atau merangkap profesi dengan memilih menjadi anggota partai politik untuk menjadi calon anggota DPR RI. Namun tidak melalui proses kaderisasi partai poltik, akibatnya dalam melaksanakan tugas sebagai wakil rakyat tidak sedikit yang paham peran dan fungsi mereka. Kekuatan yang mereka miliki hanyalah dengan mengandalkan popularitasnya sebagai figur intertaiment.

Cara lain partai politik dalam mengangkat perolehan suara partainya adalah dengan menggunakan cara-cara pragmatis, yakni dengan memasukkan kalangan "pengusaha" yang memengaruhi konstituen melalui kekuatan "politik uang". Kekuatan "politik uang" tidak hanya pada proses seleksi calon anggota legislatif, namun hingga perebutan posisi Ketua Umum Partai.

Beberapa survei menggambarkan banyaknya anggota legislatif yang tidak memperjuangkan kepentingan rakyat, namun hanya mementingkan kepentingan golongan dan partai politik. Partai politik menjadi kekuatan tersendiri tanpa adanya tanggungjawab perkaderan yang dilakukan kepada anggota partai politik untuk didistribusikan masuk dalam lembaga legislatif.

Banyak produk undang undang yang tumpang tindih satu dengan yang lainnya. Bahkan sejumlah Undang Undang yang disahkan DPR belakangan ini selalu digugat masyarakat ke Mahkamah Konsitusi (MK). Banyak orang menjadi anggota dewan karena menganggap pekerjaan tersebut bergelimang uang.

Sejauh ini, tidak ada partai politik yang memiliki pola perkaderan yang terukur untuk menentukan daftar calon anggota DPR. Semua partai politik hanya ingin cepat berkuasa dengan meraih dukungan dalam jangka pendek. Tidak ada partai politik yang secara serius melakukan perkaderan untuk menciptakan pemimpin jangka panjang, padahal perkaderan merupakan prasyarat dan tugas utama partai politik sebagai tempat menciptakan pemimpin baru. 
Banyak partai baru mengandalkan popularitas figur tertentu untuk mendulang suara dalam pemilu, bukan karena kerja infrastruktur partai. Berdasarkan pola rekrutmen anggota partai politik yang telah ada sebelumnya, maka semakin sulit membayangkan wakil rakyat periode mendatang bisa lebih baik. Bisa saja ini dijadikan risiko sistem multipartai, tetapi juga bagian dari proses demokrasi Negara Indonesia.

Putusan Badan Kehormatan atau disingkat (BK) DPR dinilai belum optimal mengarahkan anggota DPR bekerja sesuai dengan kode etik yang berlaku. Tidak hanya itu, inisiatif dan respons BK DPR terhadap pelanggaran kode etik yang dilakukan anggota DPR juga dianggap masih sangat rendah. Di sisi lain, minimnya efektivitas putusan BK atas perilaku anggota DPR tidak mampu memberikan sanksi yang optimal bagi pelanggaran kode etik. Sanksi yang diberikan belum mampu menimbulkan efek jera. Hal itu semakin membuat BK terlihat tidak optimal dan efektif dalam menjalankan tugas.

Kondisi terakhir setiap partai yang ada di BK-DPR seperti telah tersandera. Mereka sepertinya saling menutupi dan saling bersandiwara ketika ada berbagai kasus-kasus yang melilit dan menghimpit yang terjadi pada partainya masing-masing. Mereka sudah saling melindungi bila terjadi keburukan pada masing-masing. Karenanya, keberadaan BK-DPR sudah tidak efektif lagi, harus ada kekutan yang dapat mencairkan kondisi seperti ini. Oleh karena itu, ada usulan agar sebaiknya, anggota BK tidak hanya anggota DPR, harus ada orang luar, seperti Akademisi, ahli hukum, harus ada tokoh masyarakat dan harus ada ahli pemilu dan lain-lain.'

Berdasarkan uraian di atas, terdapat beberapa fakta yang hendak dibahas dalam Penulisan ini, yakni, pertama, proses perkaderan pada partai politik cenderung tidak berjalan; kedua, mudahnya untuk menjadi anggota partai politik tanpa adanya seleksi yang ketat; ketiga, penyelenggaraan pemilihan umum DPR cenderung tidak mewujudkan keterwakilan rakyat yang berkualitas; dan keempat, kinerja BK DPR cenderung tidak melakukan pengawasan yang efekif, aspiratif, berkualitas, dan bertanggungjawab terhadap anggota DPR RI. Pada tiga bagian diatas dengan mencoba nelakukan perbandingan dibeberapa negara yang menganut sistem demokrasi, berdasarkan konstitusi negara masing masing.

Pada tulisan ini, pengkajian terkait dengan rekrutmen calon parlemen, penyelenggara pemilihan umum dan pengawasan terhadap anggota parlemen dengan melakukan pendekatan komparative aproach yaitu melakukan perbandingan dengan beberapa konstitusi hingga peraturan perundang undangan serta praktik yang dilaksanakan dibeberapa negara, dengan sumber beberapa literatur baik asing maupun lokal.

Tulisan ini sesunggunya dapat bermanfaat bagi semua kalangan, namun pada kajiannya lebih banyak memberikan kotribusi pada mahasiswa program Magister dan Program Doktor sebab melakukan pengkajian pada tingkat konsep. Demikian juga sangat bermanfaat untuk kalangan praktisi hukum, 
politisi penyelenggara pemilihan umum hingga pada anggota parlemen. Sebab lebih banyak memberikan kotribusi pemikiran secara praktis untuk konstruksi dan rekostruksi pada lembaga Partai Politik, Lembaga Penyelenggara Pemilihan Umum, Lembaga DPR (Parlemen), dalam rangka melahirkan anggota parlemen sesuai dengan cita ideal keterwakilan rakyat.

Namun demikian tentu tulisan ini juga penulis sadar, bahwa begitu banyak kekurangan kekurangan yang tentunya sanat diharapkan bagi kalangan pembaca untuk melakukan kritik konsti konstruktif. Sebab bagi penulis "hadirnya buku ini di tangan pembaca maka menjadi tanda kematian penulis, semua diserahkan kepada pembaca untuk mengintpretasikan dan melanjutkan kajian kajian dalam buku ini, sebagai jalan untuk penulis hidup dan bangkit kembali untuk saling bertukar pikiran. ".......dan hanya itu."

Makassar, 16 Maret 2017

Penulis

Dr. Patawari, S.HI.,M.H. 


\section{KATA PENGANTAR \\ Oleh: Dr. Hamdan Zoelva, S.H., M.H.}

$\mathrm{U}$ ndang-Undang Dasar Negara Republik Indonesia Tahun 1945 (UUD 1945) menegaskan bahwa Negara Indonesia adalah negara yang menganut asas kedaulatan rakyat yang berdasarkan konstitusi. Selain itu, juga ditegaskan, Indonesia adalah negara hukum. Dalam pengertian tersebut mengandung makna bahwa kedaulatan rakyat tidak berjalan terpisah - tidak berjalan independen - tetapi harus berjalan dalam koridur konstitusi dan hukum, sehingga dalam kehidupan negara Indonesia, konstitusi dan hukumlah yang paling tinggi di atas kedaulatan rakyat. Dalam implementasinya, wewenang rakyat yang berdaulat untuk membentuk undangundang dasar serta undang-undang, tetapi dalam proses pembentukan undangundang dasar dan undang-undang itu harus dilakukan berdasarkan norma hukum dan konstitusi, tidak dilakukan tanpa aturan. Inilah makna kedaulatan hukum dan konstitusi yang paling konkrit.

Dalam kerangka itulah buku ini menjadi sangat bernilai. Bagaimana memahami relasi antara konsep kedaulatan rakyat dengan hukum dan konstitusi. Khususnya bagaimana melahirkan anggota lembaga perwakilan rakyat yang ideal melalui mekanisme rekrutmen dan pengawasan. Dalam negara-negara modern lembaga perwakilan rakyat adalah institusi yang sangat penting dalam kehidupan negara, karena lembaga inilah representasi utama dari rakyat dalam menjalankan kedaulatan yang dimilikinya. Artinya, jika para wakil rakyat dapat menjalankan fungsi dan tugasnya dengan baik sebagai pemegang kedaulatan rakyat, maka konsep ideal sistem perwakilan itu berjalan dengan baik pula. Norma hukum dan konstitusi dipastikan dapat lahir dari lembaga perwakilan yang demikian. Sebaliknya jika lembaga perwakilan rakyat itu, tidak melaksanakan aspirasi rakyat dengan baik, maka rusaklah konsep lembaga perwakilan itu. Demikian halnya, produk hukum yang dilahirkannya juga dipastikan tidak baik. Untuk menemukan jawaban ideal atas konsep tersebut, buku ini menganalisisnya dengan studi perbandingan.

Sebagaimana disimpulkan oleh penulis dalam buku ini, salah satu elemen menentukan untuk mencapai lembaga perwakilan rakyat yang ideal adalah anggota perwakilan rakyat itu haruslah aspiratif, berkwalitas dan bertanggung jawab. Artinya, ada konsistensi antara kehendak rakyat yang ideal dengan tindakan dan kebijakan yang dilahirkan oleh lembaga perwakilan rakyat. Tidak boleh ada gap antara kehendak rakyat dan produk lembaga perwakilan rakyat. Untuk mencapai hal demikian, proses rekrukmen dan pengawasan anggota lembaga perwakilan menjadi penting. Dalam hal ini, 
penulis merekomendasikan kebijakan strategis yang harus dilakukan untuk mewujudkan anggota parlemen yang aspiratif, berkwalitas dan bertanggung jawab adalah: Pertama, harus ada peraturan mekanisme rekrutmen calon anggota DPR yang diatur dalam aturan setiap partai politik yang memuat syarat-syarat calon yang mendukung diperolehnya anggota DPR yang aspiratif, berkualitas dan bertanggung jawab. Dalam hal ini peran partai politik menjadi sangat penting dan menentukan. Kedua, penyelenggara pemilihan umum harus berkualitas, sehingga memiliki kemampuan untuk menyelenggarakan pemilihan umum, secara profesional, berintegritas, dan akuntabel. Ketiga, perlunya lembaga lembaga pengawas yang bekerja secara efektif melalui berbagai norma dan bentuk pengawasan. Apabila ketiga langkah strategis tersebut dilaksanakan dengan baik akan melahirkan lembaga perwakilan ideal untuk melaksanakan kedaulatan rakyat. Untuk mencapai langkah strategis tersebut, harus pula dilakukan dengan instrumen norma hukum dan pelaksanannya yang baik pula sehingga diharapkan melahirkan anggota DPR yang aspiratif, berkwalitas dan bertanggung jawab. Tetapi pada sisi lain, instrumen hukum yang baik tidak akan lahir dari anggota DPR yang kacau. Di sinilah makna pentingnya mekanisme kontrol atas legislasi produk lembaga perwakilan rakyat dalam sistem konstitusional kita, yaitu peradilan konstitusi yang harus menjadi palang pintu terkahir mengawal norma hukum yang baik itu.

Buku ini berasal dari disertasi yang telah dipertahankan di hadapan dewan penguji di Fakultas Hukum Universitas Hasanuddin Makassar, saya bertindak sebagai penguji eksternal. Saya menilai, sangat bermanfaat bagi kalangan akademisi dan praktisi politik dan hukum sebagai wahana akademis untuk melakukan penataan hukum dalam rangka melahirkan anggota parlemen yang sesuai dengan konsep negara hukum dan keterwakilan rakyat.

Jakarta, April 2017

Dr. Hamdan Zoelva, SH., MH.

Ketua Mahkamah Konstitusi RI,

2013-2015 


\section{BAB I KONSEP NEGARA HUKUM}

S ebelum lebih jauh membahas tentang konsep negara hukum dalam buku ini, penulis menggambarkan beberapa varian pengertian tentang hukum dan negara. Pada masa Yunani kuno, pembicaraan tentang negara sudah menjadi bahasan para ahli filsafat. Pelanjut ide-ide Socrates adalah Plato (yang) mewariskan nilai - nilai tentang keadilan keberanian. Ia (Plato) juga mengulas tentang negara pada masa itu disebut polis. ${ }^{1}$

Pada zaman Yunani Negara itu adalah polis, yang kalau kita tinjau dari kaca mata sekarang artinya suatu negara (sebesar) Kota (City-state) dengan segala sifat-sifat khususnya, seperti misalnya demokrasi langsung, dari sinilah timbul kemudian pengertian politik. Abad pertengahan kita lihat bahwa negara itu adalah suatu "organisasi-masyarakat" yang bernama civitas terena (keduniawian) disamping civitas dei (keagamaan) dan civitas academica (ilmiah). ${ }^{2}$

Menurut Aristoteles 3 bahwa "pengertian negara hukum itu timbul dari polis yang mempunyai wilayah negara kecil, seperti Kota yang berpenduduk sedikit, tidak seperti negara-negara sekarang ini yang mempunyai negara luas dan berpenduduk banyak (Vlakte Staat). Di dalam polis itu segala urusan negara dilakukan dengan musyawarah, di mana seluruh warga negaranya yang ikut serta dalam urusan penyelenggaraan negara.

Hukum merupakan istilah Indonesia yang diambil dari bahasa Arab $\mathrm{Hukm}$

Ahmad Sukardja, Haji. 2012. Piagam Madinah \& Undang Undang Dasar NRI 1945 kajian perbandingan dasar hidup bersaa dalam masyarakat yang majemuk. Cet-I. Sinar Grafika. Jakarta. Hal: 26.

2 Padmo Wahjono, 1986. Negara Republik Indonesia. Cet. Ke-II. Cv. Rajawali. Jakarta Hal: 52.

3 Moh. Kusnardi dan Harmaily Ibrahim, 1988. Pengantar Hukum Tata Negara Indonesia Pusat Studi HTN-FHUI Jakarta. Hal: 153. Bandingkan dengan Satjipto Rahardjo 1996. Ilmu Hukum. Citra Adtya Bakri. Bandung Hal:163. 
dalam bentuk tunggal (mufrad) yang berarti putusan (Judgement) atau ketetapan (profision), yang berarti menetapkan sesuatu atas sesuatu atau meniadakannya. ${ }^{4}$ Kedua, Syariat lazim juga disebut dengan Agama (al-din/al-millah). Yaitu seperangkat hukum yang telah ditetapkan oleh Allah SWT. Untuk hambahamba-Nya yang dibawah oleh seorang Nabi di antara para Nabi (yang diutus Allah). ${ }^{5}$ Ketiga, Recht, dari bahasa Latin Rectum yang berarti bimbingan, runtutan atau pemerintahan. Sekaitan dengn Recht. Rex adalah orang yang pekerjaannya memberikan bimbingan atau memerintah. Rex di istilahkan dengan Regiment (kerajaan). Demikian juga dengan kata Derectum, Sama dengan arti Directur atau Rector. Dengan demikian bahwa Rech dapat diartikan bahwa hukum mempunyai dua unsur yaitu kewibawaan dan keadilan. ${ }^{6}$ Keempat, Siyasah, menurut Abdurrahman Taj dalam Husain Fauzy ${ }^{7}$ dalam buku berjudul Al-Islam Wa Al-siyasah. Siyasah adalah hukum-hukum dan kebijakan-kebijakan yang mengatur pelbagai urusan umat dalam bidang pemerintahan. Legislatif, yudikatif, dan seluruh jajaran eksekutif, administrasi, dan hubungan internasional dengan bangsa -bangsa lain. ${ }^{8}$ Kelima, Ius yang berarti hukum berakar dari kata iubere artinya mengatur pemerintahan. Berkaitan juga dengan iustitia atau keadilan. ${ }^{9}$ Keenam, Lex dari kata Lesere artinya mengumpulkan; mengumpulkan orang orang untuk di beri perintah.

Dari beberapa varian pengertian tentang negara dan hukum di atas bahwa Istilah negara hukum dijumpai dibeberapa literatur dengan varian istilah berdasarkan karakteristik dan sistem hukum negara masing - masing, seperti; Negara Prancis dengan istilah "etat de droit", Belanda dan Jerman lazim menggunakan istilah "rechtsstaat". Istilah "sosialist legality" dikenal di negara yang berpaham sosialis komunis. Sedangkan Inggris yang dikembangkan oleh A.V. Dicey, ${ }^{10}$ hal itu dapat dikaitkan dengan prinsip "Rule of Law" yang berkembang di Amerika Serikat menjadi jargon "The Rule of Law, and Not of Man".

Sehubungan dengan istilah negara hukum yang digunakan dibeberapa negara di atas, maka negara hukum oleh beberapa pakar dengan varian makna. Sebagaimana pandangan Meuwisen ${ }^{11}$ bahwa: "Konsep negara hukum atau negara berdasarkan atas hukum (rechtstaat atau the rule of law), yang

HA. Halfizh Dasuki 1997. Ensiklopesi Hukum Islam. PT Ichtiar Baru Van Hoeven Jakarta Hal : 571

Elizabeth A. Martin 1997. A Dictionary Of Law. Fourth Edition. Oxford University Press. New York. Hal : 259

$6 \quad$ Ahmad Sukardja, Haji. 2012. Piagam Madinah \& Undang Undang Dasar NRI 1945 Kajian Perbandingan Dasar Hidup Bersaa Dalam Masyarakat Yang Majemuk. Cet-I. Sinar Grafika. Jakarta. Hal : 36.

Ibid Hal : 37

Ibid Hal : 36 .

Ibid Hal : 36 .

10 Jimly Asshiddiqie, 2004. Cita Negara Hukum Indonesia Kontemporer, Orasi ilmiah Pada Wisuda Sarjana Hukum Fakultas Hukum Universitas Sriwijaya Palembang. 23 Maret 2004. Hal : 1.

11 Meuwisen, arti sociale rechtstaat sama dengan welvaartstaat dalam kata-kata: de moderne sosiale rechtsstaat of welvaarsstaat,...", Lihat : S.W. Couwenberg. 1981. Modern Constitutioneel Recht en Emancipatie van den Mens. Deel I. van Grocum. Assen. Hal : 41 
terhadap HAM telah dijamin pengaturannya lebih komprehensif lagi jika dibandingkan dengan UUD 1945 sebelum perubahan yang dituangkan dalam pasal-pasal HAM pada bab tersendiri yaitu Bab X A dengan judul "Hak Asasi Manusia", dan di dalamnya terdapat 10 pasal tentang HAM ditambah 1 pasal (pasal 28) dari bab sebelumnya (Bab X) tentang "Warga Negara dan Penduduk", sehingga ada 11 pasal tentang HAM mulai dari Pasal 28, 28A sampai dengan Pasal 28J.

Kedua, pemisahan/pembagian kekuasaan; bahwa UUD 1945 sebelum perubahan menganut paham pembagian kekuasaan secara vertikal, bukan pemisahan kekuasaan yang bersifat horizontal. Dalam hal ini kedaulatan rakyat dianggap terwujud penuh dalam wadah MPR yang dapat ditafsirkan sebagai lembaga tertinggi ataupun sebagai forum tertinggi. Dari sini, fungsi-fungsi tertentu dibagikan sebagai tugas dan kewenangan lembaga-lembaga tinggi negara yang ada di bawahnya, yaitu Presiden, DPR, MA, dan seterusnya. Akan tetapi, dalam perubahan pertama dan kedua UUD 1945, prinsip pemisahan kekuasaan secara horizontal jelas mulai dianut oleh para perumus Perubahan UUD 1945 seperti tercermin dalam perubahan Pasal 5 Ayat (1) dan Pasal 20 Ayat (1) sampai Ayat (5).

Ketiga, Pemerintahan berdasarkan undang-undang; bahwa Sebagai suatu negara hukum berdasarkan UUD 1945, Presiden RI memegang kekuasaan pemerintahan menurut UUD, Presiden berhak mengajukan RUU kepada DPR. Presiden menetapkan PP untuk menjalankan UU sebagaimana mestinya. Semua ketentuan UUD 1945 itu merupakan hukum positif yang menjadi dasar konstitusional (Constitutionale atau Grondwettelyke Grondslag) dari adanya sifat wetmatigheid van het bestuur, seperti yang telah termuat di dalam Pasal 4 Ayat (1) dan Pasal 5 Ayat (1) dan (2) UUD 1945.

Keempat, Peradilan administrasi yang berdiri sendiri bahwa Meskipun keberadaan peradilan administrasi (administrative court) merupakan ciri khas negara hukum liberal yang lebih mengutamakan perlindungan terhadap hak asasi individu, namun dalam negara hukum Indonesia yang berdasarkan cita negara Pancasila peradilan administrasi negara bukanlah unsur utama, melainkan unsur turunannya yang diturunkan dari unsur utama karena dalam cita Negara.

Pancasila lebih mengutamakan masyarakat dari pada individu, tetapi tidak berarti bahwa individu tidak mendapatkan tempat sama sekali melainkan harkat dan martabat manusia tetap diperhatikan. Keberadaan peradilan administrasi negara di Indonesia merupakan salah satu sarana untuk memberikan perlindungan terhadap hak asasi manusia (HAM) dengan cara melakukan pengawasan atau control judicial terhadap pemerintahan sebagai wujud pengakuan dan perlindungan terhadap hak-hak warga negara. Maka, kepada rakyat harus diberi kesempatan untuk menggugat pegawai atau instansi pemerintahan yang melakukan kesalahan dan yang menurut mereka dianggap merugikan hak-hak mereka, sehingga adanya peradilan administrasi 
diharapkan dapat memberikan jaminan tegaknya keadilan bagi tiap-tiap warga negara.

Meskipun Pasal Pasal UUD 1945 sebelum perubahan, ide negara hukum itu tidak dirumuskan secara eksplisit, tetapi penjelasannya ditegaskan Indonesia menganut ide 'rechtsstaat', bukan 'machtsstaat'. Dalam Konstitusi RIS Tahun 1949 ide negara hukum tegas dicantumkan, UUDS 1950 Indonesia adalah negara hukum dicantumkan dengan tegas. Perubahan Ketiga UUD Negara RI Tahun 1945, ketentuan negara hukum dicantumkan Pasal 1 Ayat (3) yaitu: "Negara Indonesia adalah Negara Hukum". Maka, secara teoritis gagasan kenegaraan Indonesia telah memenuhi persyaratan sebagai negara hukum modern, yaitu negara hukum yang demokratis dan bahkan menganut pula paham negara kesejahteraan (welfare-state). ${ }^{48}$

Dari uraian di atas, pada dasarnya Negara Indonesia adalah "Negara Hukum Indonesia", dengan dalil bahwa Indonesia yang berdasarkan pada UUD NRI 1945, dengan ketentuan sumber nilai, sebagaimana diuraikan berikut di bawah ini:

1. Berdasarkan "Ketuhanan" 49 bahwa pembentukan konstitusi atau UUD NRI 1945 dan penyelenggaraan negara berdasarkan pada nilai "Ketuhanan Yang Maha Esa". Sedangkan parameter (konkret) "ketuhanan" paling tidak unsurnya adalah; kemanusiaan (adil dan beradab), persatuan, kerakyatan (bijaksana, permusyawaratan, keterwakilan) dan keadilan sosial.

2. Berkedaulatan rakyat. Secara ideologi bahwa "ketuhanan" merupakan wujud kekuasaan rakyat yang menghendaki adanya "ketuhanan" sebagai dasar dalam bernegara. Dengan adanya kepercayaan (tertinggi) bahwa "ketuhanan" merupakan suatu dasar yang diyakini menyelamatkan dirinya maupun secara kolektivitas dalam penyelenggaraan negara. Sedangkan secara pragmatis bahwa kedaulatan rakyat merupakan kehendak dan keinginan masyarakat yang secara demokratis melalui perwakilan rakyat untuk mewujudkan. Nilai ketuhanan secara konkret.

3. Negara hukum. Adanya ketentuan hukum (legalitas) oleh rakyat (berdaulat) dalam suatu Negara berdasarkan nilai ketuhanan.

48 Muntoha Demokrasi dan Negara Hukum Jurnal Hukum No. 3 Vol. 16 Juli 2009 Hal : 393)

49 Sebagaimana Pidato Sokarno pada 1 Juni 1945 mengenai dasar Negara (Philosopiche Grondslag) yang menyatakan "prinsip ketuhanan! Bukan saja bangsa Indonesia ber-Tuhan, tetapi masing-masign orang Indonesia hendaknya ber-Tuhan. Tuhannya sendiri. Yang Kristen menyembah Tuhan Menurut petunjuk Isa Al-Masih, yang Islam menurut petunjuk Nabi Muhammad S.A.W. Orang Budha menjalankan Ibadatnya menurut kitab kitab yang ada padanya. Tetapi marilah kita semua ber-Tuhan. Hendaknya Negara Indonesia ialah Negara yang tiap-tiap orangnya dapat menyembah Tuhannya dengan leluasa. Segenap rakyat hendaknya ber-Tuhan. Secara beudayaan yaknu dengan tiada "egoism agama", Dan hendaknya Negara Indonesia suatu negara yang ber-Tuhan" Hamdan Zoelva. Prosiding Kongres Pancasila IV Strategi pelembagaan Nilai-nilai Pancasila dalam Menegakkan Konstitusionalitas Indonesia. PSP UGM. Yogyakarta 31 Mei -01 Januari 2012 


\section{BAB II KONSEP KEDAULATAN RAKYAT \& DEMOKRASI}

\section{A. Konsep Kedaulatan Rakyat}

Merujuk pada Black's Law Dictionary, 50 'kedaulatan' (souvereignty) diartikan sebagai supreme dominion, authority, or rule. Di dalam encyclopedia of science,, 51 dan dalam encyclopedia international, disebutkan bahwa kedaulatan itu adalah an individual or group of people, an organ or a group of organs legislates and administers the function of govermant, artinya: seseorang atau sekelompok orang, suatu badan atau sekelompok badan yang melegislasikan dan mengadministrasikan fungsi pemerintahan. Istilah kedaulatan berdasakan Ensiklopedia International ${ }^{52}$ adalah berasal dari terjemahan kata-kata seperti 'sovereignty', soverainete', sovereigniteit', 'souvereyn', superanus', 'summa pootestas', 'maiestas' (majesty).

Konsep "kedaulatan" (sovereignty) yang berarti "kekuasaan tertinggi" sudah dikenal oleh Aristoteles dan sarjana-sarjana hukum Romawi. Kedaulatan menjadi istilah politik pada abad pertengahan yang banyak dipopulerkan para sarjana Perancis. Melalui karya Jean Bodin, istilah "sovereignty" pertama kali

50 Bryan A. Garner, 1999. Black's Law Dictionary, Deluxe Eight Edition Dallas: Thompson West. Hal $: 1430$

51 Jimly Asshiddiqie. Cita Negara Hukum Indonesia Kontemporer. Orasi ilmiah Pada Wisuda Sarjana HukumFakultas Hukum Universitas Sriwijaya Palembang, 23 Maret 2004. Hal :3-8. Lihat juga: Ni'matul Huda. 2007. Lembaga Negara dalam Transisi Demokrasi. UII Press. Yogyakarta. Hal : 10

52 Jimly Asshiddiqie Islam dan kedaulatan rakyat, GEma Insani Press. Jakarta. 1995 Hal : 9. 
dihubungkan dengan negara yaitu sebagai ciri negara atau atribut negara yang membedakan negara dengan persekutuan-persekutuan lainnya Bodin melihat bahwa hakikat negara terletak pada kedaulatan itu. Di dalam segi interennya, Bodin melihat kedaulatan sebagai kekuasaan tertinggi dalam sesuatu kesatuan politik, sedangkan dalam aspek eksterennya, yaitu aspek hubungan antar negara, pertama kali dipergunakan oleh Grotius. ${ }^{53}$

Sekaitan dengan hal tersebut sebagaimanan pandangan Cynthia Weber, konsep kedaulatan (sovereignty) sebenarnya tidak memiliki kejelasan definisi, namun semua pengertian mengenai kedaulatan umumnya merujuk kepada kehidupan kenegaraan (statehood). Secara umum, pengertian kedaulatan biasanya dikaitkan dengan kekuasaan negara terhadap suatu wilayah dan masyarakat, serta relasi antar satu negara dengan negara lainnya. ${ }^{54}$

Pandangan Cynthia Weber sekaitan dengan kedaulatan yang tidak memiliki definisi (batasan/arti), menurut penulis oleh karena luasnya arti kedaulatan, maka untuk membatasi arti dari kedaulatan paling tidak menggunakan dua pandangan yaitu;

Pertama. Konsep mengenai kekuasaan tertingi dalam suatu negara, dikatakan oleh Jack H. Nagel ada dua hal penting yang terkait, yaitu lingkup kekuasaan (scope of power) dan jangkauan kekuasaan (domain of power). Lingkup kekuasaan menyangkut soal aktivitas atau kegiatan yang tercakup dalam fungsi kekuasaan, sedangkan jangkauan kekuasaan terkait dengan segala yang menjadi subjek dan pemegang kedaulatan (sovereign) 55

Kedua, Pandangan Hamid S. Attamimi menyebutkan 5 (lima) ajaran yaitu kedaulatan dalam lingkungan sendiri, kedaulatan raja, kedaulatan negara, dan kedaulatan rakyat. ${ }^{56}$ Sebagaimana Jimly Asshiddiqie ${ }^{57}$ mengatakan bahwa kedaulatan adalah konsep megenai kekuasaan tertinggi dalam suatu negara, dalam hal siapa yang berdaulat maka dikenal lima teori atau ajaran yang

53 Andi Pangerang. 1999. Prinsip permusyawaratan rakyat berdasarkan pasal 18 Undang Undang Dasar 1945 dan implementasinya dalam sistem pemerintahan dl daerah. Buku, tidak dipublikasi. PPS UNPAD. Bandung. Hal : 33

54 Cynthia Weber. 1995. Simulating Sovereignty, Interventions, The State and Symbolic Exchange. Cambridge University Press. New York: Hal :2

55 Jimly Asshiddiqie 1993. Gagagsan Kedaulatan Rakyat Dalamkonstitusi Dan Pelaksanaannya Di Indonesia: Pergeseran Keseimbangan Antara Individualism Dan Kolektifitasme Dan Kebijakan Demokrasi Politik Dan Demokrasi Politik Selama Tiga Masa Demokrasi, 1945-1980an. Buku. Tidak Terpublikasi Fakultas hukum Universitas Indonesia. Jakarta. Hal:9

56 Hamid S. Attamimi. dalam bukunya yang tidak menyebutkan tentang ajaran kedaulatan tuhan akan menggantikannya dengan ajaran kedaulatan dilingkungan sendiri. Pandangan Hamid Attamimi menggambarkan bahwa dinamika kedaulatan yang terjadi di beberapa negara. Secara umum dalam perkembangan kedaulatan pada dasarnya berawal dari kedaulatan tertinggi ada di tangan Nabi-Nabi, sebagai penjelmaan dari kedaulatan Tuhan, selanjutnya kedaulatan ada di tangan rakyat (suara rakyat suara Tuhan).

57 Jimly Ashiddiqy Jimly Asshiddiqie. Cita Negara Hukum Indonesia Kontemporer. Orasi ilmiah Pada Wisuda Sarjana HukumFakultas Hukum Universitas Sriwijaya Palembang, 23 Maret 2004. Hal. 3-8. Lihat juga Ni'matul Huda. 2007. Lembaga Negara dalam Transisi Demokrasi. UII Press. Yogyakarta. Hal :11 
IV Pembukaan UUD NRI 1945 tersebut terejawantahkan dalam Pasal 1 ayat (2) UUD NRI 1945, "Kedaulatan berada ditangan rakyat dan dilaksanakan menurut Undang-Undang Dasar".

Pada Awalnya, Pasal 1 ayat (2) UUD 1945 berbunyi "Kedaulatan adalah ditangan rakyat, dan dilakukan sepenuhnya oleh Majelis Permusyawaratan Rakyat". ${ }^{82}$ Kemudian diubah pada saat perubahan ketiga UUD NRI 1945 sehingga rumusannya menjadi "Kedaulatan berada di tangan rakyat dan dilaksanakan menurut Undang-Undang Dasar". 83

Sebagaimaan menurut Harun Al Rasyid, nyatalah bahwa paham kedaulatan rakyat memengaruhi jalan pikiran para pembuat Undang-Undang Dasar. Sedangkan alasan perubahan ini menurut Jimly Asshiddiqie "dikarenakan rumusan Pasal 1 Ayat (2) sebelum perubahan memuat ketentuan yang tidak jelas, dengan adanya ungkapan “...dilakukan sepenuhnya oleh Majelis Permusyawaratan Rakyat," maka ada yang menafsirkan bahwa hanya MPR sajalah yang melakukan kedaulatan rakyat sehingga DPR yang merupakan wakil rakyat dipandang tidak melaksanakan kedaulatan rakyat. 84

Perubahan gagasan kedaulatan dalam UUD NRI 1945 juga diiringi dengan perubahan terhadap rakyat memberikan mandat terhadap penyelenggara kekuasaan negara. Salah satu contoh yang dapat dikemukakan adalah ketika Presiden sebagai penyelenggara salah satu cabang kekuasaan negara pada awalnya dipilih oleh MPR berdasarkan UUD 1945, namun setelah UUD 1945 diamandemen, Presiden tidak lagi dipilih oleh MPR melainkan langsung oleh rakyat. Begitu juga mandat yang diberikan rakyat kepada penyelenggara kekuasaaan negara lainnya, seperti Dewan Perwakilan Rakyat (DPR) dan Dewan Perwakilan Daerah (DPD). Semua anggota DPR dan DPD dipilih melalui

82 MPR pada mulanya dipahami sebagai pemegang mandat sepenuhnya dari rakyat atau pemegang kedaulatan rakyat tertinggi, bergeser pemahaman bahwa MPR tidak lagi sebagai pemegang mandat tunggal yang tertinggi, melainkan mandat itu dilaksanakan berdasarkan Undang-Undang Dasar. Dengan demikian, mandat rakyat dijalankan oleh cabang-cabang kekuasaan negara berdasarkan UUD NRI 1945, termasuk oleh MPR sebagai salah satu lembaga penyelenggara kekuasaan negara. (Soewoto Mulyosudarmo. 2004. Pembaharuan Ketatanegaraan Melalui Perubahan Konstitusi. Asosiasi Pengajar HTN dan HAN dan In-TRANS. Malang. Hal. 3)

83 Sejak pengakuan kedaulatan oleh Belanda pada 27 Desember 1949, setidaknya rumusan kedaulatan itu mengalami dua kali koreksi: Pertama, berlakunya RIS pada kesepakatan Perjanjian Meja Bundar (KMB) di Den Haag, kedaulatan dirumuskan dalam Pasal 1 ayat (2) bahwa "Kekuasaan berkedaulatan Republik Indonesia Serikat dilakukan oleh Pemerintah bersama-sama dengan DPR dan Senat". Kedua, rumusan itu dikoreksi dalam Pasal 1 ayat (2) UUD 1945 yang berbunyi, "Kedaulatan Republik Indonesia adalah di tangan rakyat dan dilakukan oleh pemerintah bersama-sama dengan Dewan Perwakilan Rakyat." Setelah UUD 1945 yang asli sempat berlaku kembali sejak Dekrit Presiden 5 Juli 1959, maka setelah terjadi amandemen, rumusan kedaulatan kembali berubah. Pasal 1 Ayat (2) UUD 1945 yang sekarang berlaku berbunyi, "Kedaulatan berada di tangan rakyat dan dilaksanakan menurut Undang-Undang Dasar".

84 Jimly Asshiddiqie, 2005. Implikasi Perubahan UUD 1945 Terhadap Pembangunan Hukum Nasional, Sambutan Pada Seminar Pengkajian Hukum Nasional (SPHN) Oleh Komisi Hukum Nasional (KHN) Republik Indonesia. Jakarta. 21 November 2005. 
pemilihan umum. Tidak seorangpun anggota DPR dan DPD yang ditunjuk sebagaimana pernah terjadi pada masa sebelum reformasi, di mana anggota DPR, DPRD I dan DPRD II yang berasal dari ABRI tidak dipilih oleh rakyat melalui mekanisme pemilihan umum.

Perbedaan yang terjadi setelah perubahan itu sangat jelas dan prinsipil, dikarenakan: Pertama, kedaulatan yang berada ditangan rakyat itu sekarang tidak lagi dilembagakan hanya pada satu subjek ordening subject, MPR sebagai penjelmaan tunggal lembaga negara. Dalam rumusan yang baru, semua lembaga negara baik secara langsung ataupun tidak langsung juga dianggap sebagai penjelmaan dan dibentuk dalam rangka pelaksanaan kedaulatan rakyat.

Kedua, pengharusan pelaksanaan tugas menurut ketentuan undangundang dasar tidak hanya satu lembaga saja, yakni MPR, melainkan semua lembaga negara diharuskan bekerja menurut ketentuan undang-undang dasar.

Alinea ke-empat Pembukaan UUD NRI 1945 bahwa ..... maka disusunlah Kemerdekaan Kebangsaan Indonesia itu dalam suatu Undang Undang Dasar Negara Indonesia yang terbentuk dalam suatu susunan Negara Republik Indonesia yang berkedaulatan rakyat dengan berdasar kepada Ketuhanan Yang Maha Esa, Kemanusiaan yang adil dan beradab, Persatuan Indonesia, Kerakyatan yang dipimpin oleh hikmat kebijaksanaan dalam permusyawaratan/ perwakilan, serta dengan mewujudkan Keadilan sosial bagi seluruh rakyat Indonesia. ${ }^{85}$

Pandangan Afan Gaffar ${ }^{86}$ kedaulatan rakyat dengan Pemilu bahwa:

"Demokrasi sebagai suatu gagasan politik merupakan paham yang universal sehingga di dalamnya terkandung beberapa elemen sebagai berikut: 1 . Penyelenggara kekuasaan berasal dari rakyat; 2. Setiap pemegang jabatan yang dipilih oleh rakyat harus dapat mempertanggungjawabkan kebijaksanaan yang hendak dan telah ditempuhnya; 3. Diwujudkan secara langsung maupun tidak langsung; 4. Rotasi kekuasaan dari seseorang atau kelompok ke orang atau kelompok yang lainnya, dalam demokrasi peluang akan terjadinya rotasi kekuasaan harus ada, dan dilakukan secara teratur dan damai; 5. Adanya proses pemilu, dalam negara demokratis pemilu dilakukan secara teratur dalam menjamin hak politik rakyat untuk memilih dan dipilih; dan 6. Adanya kebebasan sebagai HAM, menikmati hak-hak dasar, dalam demokrasi setiap warga masyarakat dapat menikmati hak-hakdasarnya secara bebas, seperti hak untuk menyatakan pendapat, berkumpul dan berserikat dan lain-lain."

85

Wujud dari ide kedaulatan rakyat, dalam sistem demokrasi harus dijamin bahwa rakyat terlibat penuh dalam merencanakan, mengatur, melaksanakan, dan melakukan pengawasan serta menilai pelaksanaan fungsi-fungsi kekuasaan. Pelaksanaan keterlibatan penuh rakyat tersebut haruslah diorganisasikan menurut Undang-Undang Dasar sesuai dengan ketentuan UUD 1945, tidak lagi diorganisasikan melalui institusi kenegaraan Majelis Permusyawaratan Rakyat layaknya ketentuan UUD NRI 1945 sebelum perubahan.

86 Afan Gaffar. 2005. Politik Indonesia; Transisi Menuju Demokrasi. Pustaka Pelajar. Yogyakarta. Hal :15. 


\section{BAB III KONSEP KETERWAKILAN RAKYAT}

\section{A. Pengertian Perwakilan Rakyat}

Sistem negara yang memiliki lembaga keterwakilan berangkat dari pada teori kedaulatan rakyat, pertama kali diimplementasikan di Negara Inggeris sebagaimana dikemukakan oleh Rosseau "Volonte Generale atau general Will Awalnya, parlemen hanya bertugas mengumpulkan dan untuk membiayai Negara (Raja) yang digunakan untuk berperang. Namun demikian setiap pengumpulan dana yang diserahkan kepada Raja, parlemen mengikut sertakan beberapa tuntutan untuk diberikan hak -hak atau privilege sebagai imbalan atas jasa-jasa mereka. Secara terus menerus, akhirnya parlemen berhasil bertindak sebagai badan yang membatasi kekuasaan Raja yang sebelumnya berkuasa penuh (absolutism). ${ }^{87}$

87 Kata parle atau to Parle yang berarti berbicara, maka patutlah orang-orang yang duduk dalam parlemen yang bertugas untuk menyuarakan kehendak, keinginan, dan melakukan pengawasan terhadap eksekutif untuk tujuan kepentingan rakyat dalam kehidupan bernegara. Pada mulanya parlemen terdiri dari para raja, bangsawan, tuan-tuan tanah serta petinggi agama. Pada abad ke empat belas, pertemuan dengan raja dikembangkan menjadi media penghubung yang diperlukan raja. Para petinggi kerajaan diharapkan kehadiranya dalam pertemuan ini untuk dimintai informasi atau nasehat oleh raja berkenaan dengan persoalan-persoalan politik dan administrasi kerajaan yang dirasa mempengaruhi masa depan kerajaan, sejak itu pertemuan konsultasi lambat laun berkembang menjadi yang kita kenal dengan parlemen di Inggris. Pada abad ke-17 hubungan antara raja dengan parlemen berubah. Pengaruh para bangsawaan, pengusaha dan gereja dalam 
Pada masa Yunani kuno tidak dikenal konsep perwakilan. Kalaupun ketika itu sudah ada lembaga lembaga perwakilan politik, karena ada sejumlah pejabat yang dipilih dan duta yang diutus kenegara lain, lembaga ini memiliki peran kurang signifikan adalah karakteristik sistem politik Yunani kuno ketika itu yang bercorak langsung derect democras. ${ }^{88}$

Istilah perwakilan baru muncul pada masa Romawi kuno, meskipun tidak secara langsung bermakna politik. Di dalam bahasa romawi "representation" berasal dari kata "representare". Menurut Carl J. Friedrich 89 mengemukakan parlemen sebagai lembaga perwakilan rakyat (Representative assemblies), parlemen juga sebagai majelis tempat dilakukannya pembahasan (deliberative Assemblies) merupakan lembaga yang berusaha untuk memecahkan masalah dalam aktivitas masyarakat

Menurut Pitkin di dalam bahasa Latin klasik bahwa: "Representare meant simply to make present or manifest or to present againt, and it was applied almost exclusively to inanimate object". (representasi tidak memiliki kaitan sama sekali, misalnya saja, adanya orang atau sekelompok orang yang mewakili orang lain. ${ }^{90}$

Seiring berkembangnya lembaga-lembaga politik di Eropa, khusus setelah lahirnya lembaga parlemen, kata perwakilan dipakai sebagai orang atau kelompok orang yang mewakili orang lain. Pada abad ketujuh belas, kata perwakilan sudah dikaitkan dengan agency and acting for other.

Konsep perwakilan sudah berkaitan dengan adanya orang atau banyak orang lain baik bertindak sebagai delegates yaitu para wakil semata-mata hanya mengikuti pilihan yang memandang pentingnya para wali sebagai delegates. Sedangkan, trustees berarti para wakil-wakil bertindak atas orang yang diwakilinya dengan memahami permasalahan-permasalahan yang dihadapi oleh konstituen. Sedangkan, politico artinya para wakil bergerak secara continue antara delegates atau trustees.

Konsep perwakilan berasal dari teori kontrak sosial,91 dimana teori kontrak sosial ini menggambarkan proses pencapaian kesepakatan masyarakat untuk memperoleh konsentrasi kekuasaan yang diperlukan guna menjamin keberadaan dan kemampuan negara mencapai tujuan bersama.

Sebagaimana menurut Arbi Sanit 92 bahwa:

"Di dalam kehidupan penyelenggaraan negara dewasa ini, keterlibatan rakyat dalam proses pembuatan kebijaksanaan tersebut dilakukan melalui sistem perwakilan, yaitu rakyat menunjuk wakil-wakilnya yang dipandang terpercaya

kehidupan ekonomi tercermin pada keanggotaan parlemen. (Bambang Cipto. 1995. Dewan Perwakilan Rakyat. Jakarta: Raja Grafindo Persada. Hal : 2)

88 Kacung Marijan. 2011. Sistem Politik Indonesia Konsolidasi Demokrasi Pasca Orde Baru. cet ke-II. Kencana. Hal : 38

89 Friedrich, Carl J. 1949 Constitusional Governmant and democracy Theory and partice in Europe and America. Rev. ed. Boston Ginn and Company Hal : 297

$90 \quad$ Ibid. Hal : 39

91 Arbi Sanit. 1985. Perwakilan Politik Indonesia. Rajawali. Jakarta. Hal :26

92 Ibid. Hal : 208. 


\section{Perwakilan Fungsional}

Dominasi kepentingan partai politik dalam lembaga perwakilan, beberapa negara. Mencoba untuk meretasnya dengan mengikutsertakan kelompok kelompok masyarakat yang menurutnya harus diberikan perlindungan khusus hal ini didasari pada koreksi atas asas keterwakilan politik dengan pengangkatan berbagai golongan fungsional dan minoritas kedua berangkat dari pada asas Fungsional or occupation representation. Oleh Miriam Budiarjo108 mengutip dari Encyclopedia of the social aciences 109 bahwa dewasa ini perwakilan politik merupakan sistem perwakilan yang dianggap paling wajar. 110

Beberapa Negara menganggap bahwa asas Fungsional or occupation representation perlu diperhatikan dan sedapat mungkin diakui kepentingannya disamping sistem perwakilan politik, sebagai cara untuk memasukkan keahlian kedalam proses pengambilan keputusan yang menyangkut kepentingan umum. Saat ini belum terpecahkan bagaimana menentukan patokan obyektif sebagai sifat-sifat menentukan golongan fungsional yang diikutsertakan dan bagaimana menentukan kriteria untuk mengukur kekuatan golongan fungsional masingmasing.

Urgensi dari pada lembaga perwakilan rakyat memiliki dasar pemikiran yang kuat, sebagaimana pandangan Aidul Fitriciada Azhari bahwa:

"Tentang bagaimana fungsi parlemen dan peranan parlemen dari lembaga perwakila rakyat, terdapat perbedaan pendekatan antara sistem Eropa continental, yan tercermin dari sistem yang dipraktikkan dari Prancis dengan sistem Anglo saxon sebagaimana di peraktekkan di inggeris dan Amerika Serikat, perbedaan kedua hal tersebut adalah Pertama, Kemampuan rakyat mengatur diri sendiri. Kedua, Antara keharusan adanya suatu pemerintahan yang kuat dengan kedaulatan parlemen."111

Sistem Eropa Continental sebagaimana yang diperaktekkan di Perancis,

108 Miriam Budiarjo. 2008. Dasar-dasar ilmu Politik. PT gramedia Pustaka Utama. Jakarta Hal : 176

109 Encyclopedia of the social aciences. 1959. MacMillan co.. New York; Jilid V. Hal : . 522

110 Di India mengangkat beberapa orang wakil dari golongan anglo-India sebagai anggota majelis rendah: seperti golongan kebudayaan, kesusastraan, dan pekerja social. Sedangkan di Negara Pakistan mengangkat beberapa golongan dari kalangan wanita, mantan gubernur, menteri, kalangan kebudayaan, ilmuan, profesi pengacara. Negara Irlandia mengangkat golongan fungsional dipilih dan didudukkan dalam senat berdasarkan UUD 1937. Negara Republik Peranis ke-IV pada Tahun 1946 didirikan majelis khusus diluar DPR, yaitu majelis ekonomi yang berhak memperbincangkan persoalan ekonomi Negara sebagai nasihat kepada DPR. Di negara Itali pada tahun 1926 perwakilan didasarkan atas golongan ekonomi, maka dibentuk 22 "corporation" yang masing-masing mewakili industri seperti industri textil. Hal ini berangkat dari azas "Function representation". Sedangkan di Indonesia pada tahun 1971 asas perwakilan fungsional juga dikenal selain asas perwakilan politik, yaitu selain partai politik juga golongan fungsionil diikutsertakan dalam pemilihan. Demikian juga dengan yang terjadi di Papua yang dikenal dengan Majelis Rakyat Papua (MRP) dengan berdasar Pasal 19 Undang Undang No. 21 Tahun 2001 tentang Otonomi Khusus bagi Provinsi Papua bahwa "Majelis Rakyat Papua (MRP) beranggotakan orangorang asli Papua yang terdiri atas wakil-wakil adat, wakil-wakil agama, dan wakil-wakil perempuan yang jumlahnya masing-masing sepertiga dari total anggota MRP.

111 Munir Fuadi. 2010. Konsep negara demokrasi. Refika Aditama. Jakarta. Hal : 31 
terutama sistem yang dibangun setelah revolusi Perancis, justru memberikan kekuatan dan kewenangan yang besar kepada parlemen sebagai lembaga kterwakilan rakyat, dengan asumsi -asumsi sebagai berikut;

a. Keputusan dari lembaga perwakilan rakyat benar-benar merepresentasikan kehendak dari rakyat.

b. Terdapat suatu kehendak rakyat yang disebut sebagai "kehendak bersama" sebagaimana diajarkan oleh Rosseau dalam ajaran La Volonte generale

c. Kehendak rakyat mengikat semua individu secara moral

d. Demokrasi di Eropa continental, seperti di Perancis, lebih bersifat kolektif, meskipun ada konsep perlindungan hak-hak sipil rakyat, tetapi perlindungan tersebut dilihat sebagai bagian dari kehendak dari kolektivitas tersebut. Karena itu, eksistensi suatu Majelis Nasional di Perancis lebih dipandang sebagai Majelis yang mewakili seluruh komponen bangsa. Sementara itu, sistem demokrasi di Amerika Serikat dan di Inggeris, lebih menekankan kepada aspek individual manusia, karena itu perlindungan hak-hak sipil rakyat lebih kuat.

Menurut Miriam Budiardjo,112 bahwa dalam praktik, asas perwakilan politik diragukan kewajarannya. Maka untuk menggenapi masalah ini diusahakan agar diganti atau sekurang-kurangnya dilengkapi dengan asas perwakilan fungsional functional or occupational representation. Pemikiran ini dilatarbelakangi anggapan bahwa negara modern dikuasai oleh bermacammacam kepentingan ekonomi, yang dalam sistem perwakilan politik sama sekali tidak dihiraukan dan tidak dilibatkan dalam proses politik. Oleh karena itu, pemilih harus diberi kesempatan untuk memilih golongan ekonomi dan profesi, di mana ia bekerja tidak semata-mata menurut golongan politiknya seperti yang terjadi dalam karakter perwakilan politik.

Mekanisme rekrutmen politik dalam pemilihan umum penting untuk seleksi orang-orang yang akan duduk dalam lembaga perwakilan, dengan berdasar pada asas langsung, umum, bebas, rahasia, jujur, adil dan kompetitif.

Berdasarkan UUD NRI 1945 yang dapat dikategoriakn sebagai lembaga perwakilan rakyat di Indonesia adalah sebagai berikut:

a. Majelis Permusyawaratan Rakyat republik Indonesia (MPR-RI)

b. Dewan perwakilan Daerah (DPD)

c. Dewan Perwakilan Rakyat Republik Indonesia (DPR-RI)

d. Dewan Perwakilan Rakyat Daerah Provinsi (DPRD-Provinsi)

e. Dewan Perwakilan Daerah Kabupaten/Kota (DPRD Kabupaten).

f. Badan Perwakilan Desa (BPD) 


\section{BAB IV PARTAI POLITIK}

$\mathrm{S}$ tudi partai politik dimulai pada Pada abad ke-20, beberapa sarjana yang memelopori antara lain ${ }^{113}$ adalah M. Ostogorsky (1920), Robert Michels (1911), Maurice Duverger (1951) dan Sigmund Neumann (1956). Setelah itu beberapa sarjana Behavioralis, seperti Joseph Lapalombara dan Myron Weiner, secara khusus meneropong masalah partai hubungannya dengan pembangunan politik. Kedua sarjana ini menuangkan pikiran dan hasil Penulisannya dalam buku yang berjudul Political Parties and Political development (1966).

Partai politik pertama-tama lahir di negara-negara Eropa Barat.114 Seiring dengan meluasnya gagasan bahwa rakyat merupakan faktor yang perlu diperhitungkan serta diikutsertakan dalam proses politik, maka partai politik telah lahir secara spontan dan berkembang menjadi penghubung antara rakyat disatu pihak dan pemerintah pihak lain. Partai politik umumnya dianggap sebagai manifestasi dari suatu sistem politik yang sudah modern atau sedang dalam proses memodernkan diri. Sehingga tidak heran jika di negara-negara koloni dan pasca koloni partai sudah menjadi lembaga politik yang sangat berpengaruh.

Konteks ke Indonesiaan, partai politik pertama lahir pada masa kolonial, motivasi lahirnya beberapa partai adalah didasarkan pada masing-masing tujuan dan kepentingan, seperti Budi Oetomo dan Muhammadiyah yang tujuan gerakannya pada ranah sosial, khususnya melalui pendidikan; partai Sarekat

\footnotetext{
113 Josep Lapalombara dan Myron Weiner. 1966. Politcal Parties and political Development Princeton. Princeton university Press. .

114 Mirim Budiarjo. 1991. Dasar-Dasar Ilmu Politik. Hal :159
} 
Islam (SI) dan Partai Katolik yang berbasis pada gerakan keagamaan demi perbaikan ekonomi masing-masing umatnya; juga Partai Komunis Indonesia (PKI) dan Partai Nasional Indonesia (PNI) dengan spirit sekuler yang memproklamirkan kesadaran nasionalisme komunisme bagi rakyat Hindia Belanda.

Tahun 1908 Boedi Oetomo (BO) berdiri, kehadirannya diawali dengan aktivitas sosial dalam bidang pendidikan. Walaupun masih sebatas pendidikan bagi orang Jawa, BO mengalami peningkatan jumlah anggota yang cukup signifikan. Peningkatan tersebut membuat $\mathrm{BO}$ berubah nama menjadi Budi Utama (BU) yang kemudian berafiliasi ke dalam Partai Indonesia Raya (Parindra). Pada tahun 1935 bersama-sama Persatuan Bangsa Indonesia (PBI) yang awalnya bernama Indonesiashe Studie Club Surabaya (1924), Boedi Utama lambat laun berkembang ke arah organisasi yang bertujuan politik. Pada tahun 1911 berdiri Sarekat Dagang Islam (SDI) yang kemudian tahun 1923 menjadi Sarekat Islam (SI) dan tahun 1929 menjadi Partai Sarekat Islam Indonesia (PSII). Menurut A.K. Pringgodigdo, SI berbeda dengan Budi Utama yang merupakan organisasi kaum atasan. SI ini sejak berdirinya diarahkan pada rakyat jelata, hal ini dapat dilihat dalam statuta akta notaris SI tanggal 10 September 1912 yang memuat kalimat "memajukan kepentingan rohani dan jasmani.115

Beberapa tujuan lahirnya partai politik di Indonesia diawali dengan adanya idelologi dari masing-masing partai, sehingga partai yang muncul beraneka ragam yang kemudian menjadi cikal bakal Indonesia sebagai penganut sistem multipartai.

\section{B. Pengertian Partai Politik}

Pada negara yang demokrasi pemilihan umum atau disingkat dengan Pemilu ditandai dengan keikutsertaan partai politik sebagai peserta Pemilu. Dapat dikatakan bahwa partai politik itu pada pokoknya memiliki kedudukan (status) dan peranan (role) yang sentral dan penting dalam setiap sistem demokrasi. Partai politik biasa disebut sebagai pilar demokrasi, karena mereka memainkan peran yang penting sebagai penghubung antara pemerintah negara (the state) dengan warga negaranya (the citizens). ${ }^{116}$

Menurut Schattscheider pada Tahun 1942 dalam Jimly Asshiddiqie, PokokPokok Hukum Tata Negara Indonesia, pasca Reformasi dikatakan "Political parties created democracy" partai politiklah yang membentuk demokrasi, bukan sebaliknya. Oleh sebab itu, partai politik merupakan pilar atau tiang yang perlu dan bahkan sangat penting untuk diperkuat derajat pelembagaannya (the degree of institutionalization) dalam setiap sistem politik yang demokratis.117 Beberapa

115 Rusdi Kantaprawira. 1985. Sistem Politik Indonesia Suatu Model Pengantar. Sinar Baru Algensindo. Cet. ke-IV Bandung. Hal:75

116 Jimly Asshiddiqie. 2007. Pokok-Pokok Hukum Tata Negara Indonesia Pasca Reformasi.PT Bhuana Ilmu Populer. Jakarta. Hal : 709-710.

117 Ibid. Hal. 710. 
siapa saja yang bakal menjadi calon pemimpin di dalam negaranya, karenanya pengumuman hasil pemenang dari kompetisi tersebut dilaksanakan secara terbuka dan terang-terangan. Pada praktiknya prosedur ini dikenal dengan istilah Luber (langsung, umum, bebas, dan rahasia) dan Jurdil (jujur dan adil).

Pada praktik rekrutmen politik, umumnya terdapat beberapa jenis jalur politik, yaitu:

a. Jalur rekrutmen berdasarkan kemampuan. Kemampuan dari kelompok atau individu tertentu dalam jalur ini menjadi kriteria dasar bagi perekrutan seseorang. Hal ini didasarkan pada penilaian distribusi kekuasaan, dan bakat-bakat yang terdapat di dalam masyarakat yang secara langsung atau tidak langsung menguntungkan bagi partai politik. Hal ini penting untuk dipahami sebagai pertimbangan bahwa tidak mudah menjadi seorang pemimpin. Olehnya itu, kita harus memiliki kecakapan dan keahlian untuk masuk ke dunia politik.

b. Jalur rekrutmen berdasarkan kaderisasi artinya partai politik harus menyeleksi dan mempersiapkan seluruh anggotanya yang dianggap mampu dan cakap untuk mendapatkan jabatan politik tertentu. Selain itu, mampu memobilisasi partai politiknya hingga memberi pengaruh signifikan dalam masyarakat. Jalur ini menjadi salah satu tujuan pendirian partai politik. Seperti yang ditulis Almond dan G. Bigham Powell: "rekrutmen politik tergantung pula terhadap proses penyeleksian dalam partai politik itu sendiri". Jadi, setiap individu harus memiliki kecakapan dan keahlian sebagai modal dasar dalam menapaki jenjang kaderisasi politik yang bermuara pada jabatanjabatan penting suatu negara.

c. Jalur rekrutmen politik berdasarkan ikatan primordial. Yaitu hubungan kekerabatan yang dekat antara orang yang memiliki jabatan politik tertentu dengan yang berkepentingan untuk terlibat dalam partai politik dengan tujuan tertentu. Terlepas apakah orang yang berkepentingan itu memenuhi kriteria atau tidak, misalnya ketika seorang Raja wafat, dengan sendirinya kekuasaan Raja dilimpahkan pada anaknya, atau keluarga besar, menantu lelaki, karena dianggap memiliki persamaan marga atau suku.

Adapun Ramlan Surbakti, ${ }^{126}$ terkait rekrutmen politik secara prosedural memberikan pandangan bahwa:

Rekrutmen politik mencakup pemilihan, seleksi, dan pengangkatan seseorang atau sekelompok orang untuk melaksanakan sejumlah peranan dalam sistem politik pada umumnya dan pemerintah pada khususnya.

Pada umumnya, para ilmuwan politik biasa menggambarkan adanya 4 (empat) fungsi partai politik Menurut Miriam Budiardjo,127 dalam negara

126 Ramlan Surbakti. 1999. Memahami Ilmu Politik. Gramedia Widiasarana. Jakarta. Hal :25

127 Miriam Budiardjo. 2003. Dasar-Dasar ilmu Politik. Gramedia Pustaka utama. Jakarta. Hal :164 
demokrasi partai politik menyelenggarakan beberapa fungsi, yaitu :

1. Partai sebagai sarana komunikasi politik

2. Sarana sosialisasi politik

3. Partai politik sebagai sarana rekrutmen politik

4. Partai politik sebagai sarana pengatur konflik conflict management.

Partai politik sebagai sarana komunikasi politik dimaksudkan agar partai politik bertugas menyalurkan pendapat masyarakat sehingga tidak terjadi simpang siur. Meminimalkan kesimpangsiuran para anggota partai politik atau konstituen masing-masing partai. Namun kini, dalam kehidupan masyarakat yang semakin kompleks, aspirasi yang disampaikan rakyat tidak langsung diterima dan direalisasikan, melainkan ditampung lalu kemudian disalurkan, setelah sebelumnya dilakukan perumusan ditingkat internal partai politik.

Partai politik berfungsi untuk menyosialisasikan segala produk pemerintah kepada seluruh masyarakat, misalnya peraturan dalam bentuk undang undang, dan seluruh bentuk kebijakan yang dikeluarkan oleh pemerintah yang harus diterima oleh warganegara.

Sebagaimana dikatakan oleh Larry Diamond,128 bahwa:

Untuk menegakkan demokrasi partai politik harus memiliki salah satu tujuan utamanya yang meliputi, pembentukan masyarakat politik yang demokratis, partai-partai politik yang demokratis, dan mekanisme kampanye yang melalui persaingan untuk menduduki posisi politik berproses yakni dengan pemilihan yang teratur, bebas, jujur, adil dan dalam suasana damai.

Berdasarkan fungsi di atas, maka; partai politik menjadi medium efektif untuk menjembatani sikap tranparansi pemerintah kepada masyarakat. Sehingga pada pelaksanaan pemerintahan masyarakat lebih memahami tugas dan tanggungjawabnya. Partai politik sebagai sarana rekrutmen politik dipersiapkan menjadi pemimpin dalam pemerintahan. Olehnya itu, partai politik harus mampu menyediakan generasi yang memahami teks dan konteks kenegaraan. Partai politik sebagai sarana pengatur konflik mengandung arti, bahwa diberbagai kalangan masyarakat sering terjadi kesalahpahaman antara partai politik yang satu dengan partai politik lainnya, demikian pula antara anggota partai politik dengan partai politiknya. Kehadiran partai politik disini mampu mengeliminir terjadinya kesalah pahaman tersebut.

Mekanisme hubungan partai politik dengan masyarakat sederhananya adalah partai politik membutuhkan suara pemilih dalam pemilihan umum. Maka partai politik harus memerhatikan keinginan pemilih sebelum mengambil keputusan dan melaksanakan program partai. Artinya, politisi harus mencari informasi tentang masalah yang sedang dihadapi masyarakat serta kepentingan dan preferensinya.

128 Larry Diamon. 1994. Revolusi Demokrasi perjuangan untuk kebebasan dan pluralism di Negara sedang berkembang. Diterjemahkan oleh yayasan obor Indonesia. Jakarta. Hal : 10 


\section{BAB V \\ REKRUTMEN ANGGOTA PARLEMEN DI BEBERAPA NEGARA}

\section{A. Konsep Rekrutmen Anggota Parlemen}

Proses menuju lembaga Dewan Perwakilan Rakyat atau disingkat dengan DPR diperlukan adanya rekrutmen calon anggota DPR yang mengisi lembaga DPR. Lembaga DPR diharapkan mampu membawa aspirasi rakyat sesuai dengan ketentuan peraturan perundang undangan yang berlaku di negara Indonesia.

Rekrutmen harus mengacu pada UUD NRI 1945, dan peraturan perundang undangan. Sebagaimana ketentuan UUD NRI 1945 bahwa "Negara Indonesia adalah negara hukum", 129 Korelasi antara negara hukum dan negara yang berkedaulatan rakyat sebagaimaan diatur dalam UUD NRI 1945 bahwa "Kedaulatan berada ditangan rakyat dan dilaksanakan menurut UndangUndang,"130 bahwa negara Indonesia adalah Negara yang berkedaulatan rakyat berdasarkan UUD NRI 1945, bersumber pada nilai “Ketuhanan Yang Maha Esa" 131

Ada tiga indikator dalam mengisi posisi anggota DPR pertama, calon

Lihat : Pasal 1 Ayat (3) UUD NRI 1945

Lihat: Pasal 1 ayat (2) UUD NRI 1945

131 Ditafsirkan bahwa kedaulatan rakyat adalah berdasar pada nilai "Ketuhanan Yang Maha Esa". Asumsiny bahwa perikemanusiaan, keadilan individu, keadilan sosial, keadaban (etika), persatuan, dan musyawarah. sesungguhnya terangkum dalam nilai "Ketuhanan Yang Maha Esa". 
anggota adalah warga Negara atau Rakyat Indonesia yang memiliki hak dan kewajiban sesuatu peraturan perundang undangan. Hal ini menjadi persoalan dasar bahwa seiring dengan perubahan konstitusi (UUD NRI 1945) sebag dengan adanya perubahan tersebut berimplikasi bahwa orang asing sekalipun juga dapat menjadi warganegara Indonesia dan menajdi anggota DPR. Kedua, bahwa calon anggota DPR adalah mengikuti dan memenuhi syarat sesuai ketentuan hukum, misalnya adalah harus anggota partai politik. Diskursus terkait anggota partai politik problemnya bahwa jika partai politik kurang memberikan pembobotan (pembekalan) kepada anggotanya maka cenderung anggota DPR yang terpilih tidak memiliki kompetensi dalam menjalankan tugasnya sebagai anggota DPR. Ketiga, berdasarkan Ketuhanan Yang Maha Esa, di gambarkan bahwa calon anggota DPR mempunyai integritas, moralitas yang sesuai dengan nilai nilai ketuhanan/Agama. Kesempatan ini tentu sesuai dengan agama / kepercayaan masing masing calon.

Penentuna Dewan Perwakilan Rakyat sebagai manifestasi dari keterwakilan rakyat, atau kedaulatan rakyat yang terlembagakan pada pemerintahan dalam arti luas, DPR merupakan lembaga yang berperan dan berfungsi sebagai lembaga menerima aspirasi rakyat, mengurus masalah keuangan negara, melakukan kontroling terhadap pemerintahan eksekutif, dan membuat regulasi.

Pengelolaan Negara oleh masyarakat secara demokrasi sebagaimana pandangan Abraham Lincoln dari rakyat oleh rakyat dan untuk rakyat adalah dituangkan dalam suatu ketentuan hukum, hubungannya dengan Pasal 1 Ayat (3) UUD NRI 1945 bahwa132 "Negara Indonesia adalah negara hukum". Asumsi tersebut, jika dikorelasikan maka Ketuhanan sebagai sumber Nilai, sedangkan negara hukum sebagai ketentuan hukum Negara Republik Indonesia. ${ }^{133}$

132 Lihat: Pasal 1 Ayat (3) UUD NRI 1945

133 Pengelolaan suatu Negara adalah berdasar pada suatu nilai Ketuhanan. Bahwa Tuhan merupakan sumber nilai tertinggi dalam kehidupan manusia. Manusia membentuk suatu kelompok yang terorganisir (Negara) adalah untuk memenuhi kebebasan (hasrat dan keinginannya) sebagai makhluk individu dan sosial. Namun demikian, pertama, manusia sekalipun memiliki peran dalam behubungan dengan manusia lain, akan tetapi berdasar pada suatu norma Tuhan atau nilai Ketuhanan. Kedua, pada kedaulatan rakyat (warganegara) sesungguhnya bukanlah kedaulatan (kekuasaan) yang tak terbatas, kekuasaan rakyat dibatasi oleh norma Ketuhanan. Maka manusia sebagai pemerintah di dalam mengelolah Negara, harus berdasar pada suatu nilai-nilai dan norma Ketuhanan. Ketiga, ketentuan hukum merupakan suatu ketentuan yang terlahir dari hasrat dan keinginan manusia, namun hasrat dan keinginan manusia tersebut berdasar pada nilai ketuhanan. Maka, ketentuan hukum terlahir dari manusia dengan berdasar pada nilai Ketuhanan tujuannya adalah selamat atau keselamatan. Keempat, Jika, tujuan hidup manusia adalah keselamatan. Maka hukum hanya dapat dibentuk oleh orang-orang yang memiliki kompetensi, bukan terlahir dari kehendak dan keinginan masyarakat secara umum, Maka harusnya orang -orang yang memiliki kompetensi tersebut diatur dalam ketentuan hukum, untuk mengatur demokrasi dalam rangka melahirkan hukum yang berkualitas demi tercapainya kesejahteraan agama, bangsa, dan negara. Itulah sehingga penulis kerap berpandangan bahwasanya tujuan akhir dari Hukum adalah keselamatan. Kepastian, kemanfaatan dan keadilan merupakan instrument mencapai keselamatan itu sendiri. 


\begin{abstract}
Parliament;
b. "group" means a group of not less than 3 but not more than 6 candidates nominated for any election in any group representation constituency;

c. "person belonging to the Malay community" means any person, whether of the Malay race or otherwise, who considers himself to be a member of the Malay community and who is generally accepted as a member of the Malay community by that community;

d. "person belonging to the Indian or other minority communities" means any person of Indian origin who considers himself to be a member of the Indian community and who is generally accepted as a member of the Indian community by that community, or any person who belongs to any minority community other than the Malay or Indian community. ${ }^{154}$
\end{abstract}

Mekanisme pencalonan wakil rakyat pada Negara Singapore menggunakan sistem Group representation constitution atau keterwakilan dari kelompok yang telah ditentukan dalam konstitusi, bahwa:

Pertama, harus dipastikan bahwa calon wakil rakyat adalah mereka sebagai warganegara yang berasal dari kelompok Melayu, India dan masyarakat minoritas lainnya. Singapure memberikan batasan pada kelompok tertentu.

Kedua, Presiden telah menyatakan bahwa mereka berasal dari kelompok keterwakilan rakyat dari kelompok mereka dengan memperhatikan jumlah pemilih di daerah pemilihan.

Ketiga, pada masing-masing daerah pemilihan untuk keterwakilan kelompok yang dimaksud adalah ditentukan keterwakilan menjadi calon tidak kurang dari 3 (tiga) orang dan tidak lebih dari 6 (enam) calon.

Keempat, selain dari pada ketentuan syarat calon anggota legislatif Qualifications for membership of Parliament155 maka Presiden menentukan mengenai asal kelompok masing-masing calon, dalam hal ini adalah apakah berasal dari kelompok Melayu, atau minoritas India, dan atau kelompok lainnya.

Kelima, dengan adanya ketentuan Presiden mengenai asal kelompok mereka maka pada penentuannya keterwakilannya adalah dilakukan komite (pelaksana Pemilu) untuk menentukan masing-masing calon sebagai keterwakilan dari kelompok Melayu atau minoritas India atau lainnya.

Keenam, dengan adanya kandidat yang berasal dari partai atau sebagai

154 "Pemilihan" berarti pemilihan untuk tujuan pemilihan Anggota Parlemen; _ "kelompok " berarti kelompok tidak kurang dari 3 tetapi tidak lebih dari 6 calon yang diusulkan untuk setiap pemilu dalam setiap konstituensi perwakilan kelompok; _ "orang milik masyarakat Melayu " berarti setiap orang, baik dari ras Melayu atau sebaliknya, yang menganggap dirinya sebagai anggota dari masyarakat Melayu dan yang secara umum diterima sebagai anggota dari komunitas Melayu oleh masyarakat itu; _ _ orang milik masyarakat minoritas India atau lainnya " berarti setiap orang asal India yang menganggap dirinya sebagai anggota dari komunitas India dan yang secara umum diterima sebagai anggota dari masyarakat India dengan itu masyarakat, atau orang yang milik untuk setiap komunitas minoritas selain komunitas Melayu atau India; 
calon individu (independen) adalah masing-masing diklasifikasi sebagai calon wakil dari kelompok masing-masing.

Negara Singapore menghendaki adanya calon anggota legislatif yang berasal dari kelompok kelompok Melayu, India dan masyarakat minoritas lainnya. Hal ini serupa dengan Negara Iran, Thailand. Negara Iran menghendaki adanya keterwakilan rakyat pada sektor kepercayaan agama, seperti Zorroaster, Kristen. Sedangkan negara Thailand adanya kelompok profesi dan Singapore adalah keterwakilan pada kelompok kesukuan atau masyarakat minoritas. Sedangkan Indonesia adalah hanya pada kelompok perempuan dengan adanya keterwakilan $30 \%$ perempuan.

\section{Negara Republik Indonesia (Dewan Perwakilan Rakyat)}

Mekanisem rekrutmen calon anggota DPR di negara Indonesia ditentukan dalam Undang-Undang Nomor 8 Tahun 2012 dengan ketentuan bertakwa kepada Tuhan Yang Maha esa, menjadi anggota partai politik, dicalonkan oleh satu partai politik, dicalonkan dari satu distrik pemilihan, dan adanya ketentuan pertimbangan $30 \%$ calon dari unsur perempuan.

Mekanisme calon anggota DPR pada Negara Indonesia tidak ditentukan secara rinci di dalam UUD NRI 1945, namun diamanatkan di dalam peraturan perundang undangan, untuk selanjutnya dilaksanakn oleh partai politik.

Pada Tahun 1971 negara Indonesia menggunakan sistem perwakilan fungsional juga dikenal selain asas perwakilan politik, yaitu selain partai politik juga golongan fungsionil diikutsertakan dalam pemilihan. Demikian juga dengan yang terjadi di Papua yang dikenal dengan Majelis Rakyat Papua (MRP) dengan berdasar Pasal 19 Undang Undang No. 21 Tahun 2001 tentang Otonomi Khusus bagi Provinsi Papua bahwa "Majelis Rakyat Papua (MRP) beranggotakan orang-orang asli Papua yang terdiri atas wakil-wakil adat, wakilwakil agama, dan wakil-wakil perempuan yang jumlahnya masing-masing sepertiga dari total anggota MRP. 


\section{BAB VI}

\section{MEKANISME REKRUTMEN ANGGOTA PARLEMEN DI BEBERAPA NEGARA}

$\mathrm{C}$

ara kerja beberapa negara dalam melaksanakan rekrutmen calon anggota DPR bervariasi, namun demikian, terdapat kesamaan yang paling tidak dapat menjadi acuan pada rekrutmen (lihat Tabel I). Uraian pada Tabel I memberi gambaran tentang mekanisme rekrutmen calon anggota DPR (parlemen) di Indonesia dan beberapa negara, seperti Chile, Brasil, Iran, Jerman, Itali, Thailand, dan Singapore.

Dari beberapa ketentuan sebagaimana dalam konstitusi di beberapa negara, mekanisme yang tepat dalam mewujudkan anggota DPR yang aspiratif adalah:

Pertama, Anggota Partai. Bahwa untuk menjadi calon anggota DPR adalah sebagai ketentuan dasar bahwa harus sebagai anggota partai politik. Hal tersebut sebagaimana dengan beberapa negara yakni; Chile, Jerman dengan melakukan seleksi tingkat lokal, bebas campur elit partai di tingkat regional atau nasional, Negara Itali, elit politik tidak hanya diseleksi dari parpol juga kelompok masyarakat. Sedangkan Negara Brasil ketentuannya adalah anggota partai Minima 1 (satu) Tahun. Sedangkan Negara Indonesia Menjadi anggota Partai Politik Peserta Pemilu.

Kedua, adanya survey Pra Pemilihan Umum: sebagaimana dilaksanakan oleh Negara Chile yakni dengan adanya survei pra pemilu yang dilaksanakan oleh Partai pilitik peserta pemilihan umum.

Ketiga, adanya Kelompok agama: di Negara Iran, mekanisme pencalonan adalah dengan adanya kuota 1 (satu) kursi masing-masing: Zoroaster, Yahudi, Kristen Assyria, Chaldean. 
Tabel 1. Mekanisme rekrutmen calon anggota perlemen di beberapa negara.

\begin{tabular}{|c|c|c|}
\hline No & Negara & $\begin{array}{c}\text { Mekanisme rekrutmen calon anggota perlemen } \\
\text { berdasarkan konstitusi }\end{array}$ \\
\hline 1. & Chile & $\begin{array}{l}\text { - Loyalis partai } \\
\text { - } \text { Adanya survei pra pemilu. } \\
\text { - Min } 3 \text { tahun di daerah pemilihan (distrik) }\end{array}$ \\
\hline 2 & Iran & $\begin{array}{l}\text { - } 1 \text { kursi : Zoroaster, Yahudi, Kristen Assyria, Chaldean } \\
\text { - Ketidak layakan: orang yang memainkan peran utama dalam } \\
\text { memperkuat rezim sebelumnya (pra-Islam), }\end{array}$ \\
\hline 3 & Brasil & $\begin{array}{l}\text { - Tidak ada calon independen } \\
\text { - Anggota Partai Minimal } 1 \text { Tahun }\end{array}$ \\
\hline 4 & Jerman & $\begin{array}{l}\text { - Anggota Partai } \\
\text { - Adanya seleksi tingkat lokal, (bebas campur elit partai di tingkat } \\
\text { regional atau nasional) }\end{array}$ \\
\hline 5 & Italia & $\begin{array}{l}\text { - Rekrutmen bukan hanya untuk perwakilan (Parlemen) } \\
\text { - Elit politik tidak hanya diseleksi dari parpol juga kelompok } \\
\text { masyarakat. } \\
\text { - Calon dapat dari luar negeri }\end{array}$ \\
\hline 6 & Thailand & $\begin{array}{l}\text { - Nasional Legislatif Majelis diangkat oleh Raja } \\
\text { - kelompok pemerintahan, swasta, sosial dan akademik dan daerah } \\
\text { - anggota parpol }\end{array}$ \\
\hline 7 & Singapore & $\begin{array}{l}\text { - Keterwakilan Melayu, India, dan masyarakat minoritas. } \\
\text { - Ada calon independen } \\
\text { - Minim } 3 \text { dan maksimal } 6 \text { dari keterwakilan kelompok dalam } \\
\text { pemilihan. }\end{array}$ \\
\hline 8 & Indonesia & $\begin{array}{l}\text { - Bertakwa kepada Tuhan Yang Maha Esa } \\
\text { - Menjadi anggota Partai Politik Peserta Pemilu. } \\
\text { - Dicalonkan hanya di } 1 \text { (satu) lembaga perwakilan; dan } \\
\text { - Dicalonkan hanya di } 1 \text { (satu) daerah pemilihan. } \\
\text { - Pengajuan calon oleh partai politik. } \\
\text { - } 30 \text { persen perempuan. }\end{array}$ \\
\hline
\end{tabular}

Sumber: (Diolah berdasarkan konstitusi masing-masing Negara)

Keempat, kelompok masyarakat; sebagaimana Negara Singapura dengan ketentuan adanya keterwakilan kelompok Melayu, India, dan masyarakat minoritas (minimal 3 (tiga) dan maksimal 6 (enam) orang keterwakilan di daerah pemilihan. Sedangkan Negara Thailand dengan adanya kelompok pemerintahan, swasta, sosial dan akademik dan daerah. Sedangkan Negara Indonesia pengajuan calon oleh partai politik dengan adanya 30 persen perempuan.

Ketujuh, lama tinggal daerah pemilihan (distrik) sebagaimana ketentuan negara Chile bahwa calon anggota DPR adalah menetap minimal 3 (tiga) Tahun di daerah Pemilihan (distrik). Sedangkan Negara Brasil ketentuannya bahwa mereka yang menjadi calon harus juga hidup dalam negara / konstituen selama 1 (satu) Tahun sebelum pemilihan umum. Sedangkan Negara Thailand bahwa keterwakilan legislatif Negara Thailand adalah berasal dari daerah (distrik) masing-masing. 
(2) Rekrutmen sebagaimana dimaksud pada ayat (1) huruf c dan huruf d dilakukan secara demokratis dan terbuka sesuai dengan AD dan ART serta peraturan perundang-undangan.

(3) Penetapan atas rekrutmen sebagaimana dimaksud pada ayat (1), ayat (1a), dan ayat (2) dilakukan dengan keputusan pengurus Partai Politik sesuai dengan AD dan ART.

Terkait dengan mekanisme rekrutmen calon anggota DPR berdasarkan amanat undang undang, diatur dalam ketentuan AD/ART partai politik.

Berdasarkan pada hubungan antara Undang Undang Partai Politik dan AD/ART Partai Politik merupakan mata rantai yang tidak tepisahkan. AD/ART partai Politik seharusnya mengikuti ketentuan Undang Undang Partai Politik. Sehingga penafsiran UU No. 2 Tahun 2011 tentang parpol antara Pasal 2 ayat (4) dengan Pasal 29 ayat (1) huruf b merupakan ketentuan dasar untuk semua partai politik mengatur mekanisme rekrutmen calon anggota DPR di dalam AD/ART Partai Politik. Bukan pada $\mathrm{PO}$ atau Peraturan Oragnisasi partai Politik.

Bahwasanya, jika dilakukan berdasarkan PO atau peraturan lainnya tentu dari awal rekrutmen calon anggota DPR tidak mencerminkan aspiratif. Sebab, jika dilakukan dalam PO tentunya hanya di tetapkan oleh segelintir pengurus pada partai politik. Sebaliknya, jika mekanisme rekrutmen calon anggota DPR ditetapkan dalan AD/ART maka akan lebih mencerminka aspiratif dan terbuka oleh karena AD/ART diketahui oleh anggota partai politik, paling tidak perwakilan yang menjadi peserta pada kongres atau dalam rapat keputusan tertinggi pada partai politik.

B. Rekrutmen calon anggota Dewan Perwakilan Rakyat berdasarkan AD/ART Partai Politik

Partai politik yang melaksanakan mekanisme rekrutmen calon anggota DPR, yang diatur dalam AD/ART Partai Politik. Guna mengukur sejauhmana ketentuan mekanisme rekrutmen yang dilaksanakan oleh partai politik, dapat dilihat pada Tabel II.

Secara umum partai politik bersifat nasional, adanya AD/ART, fungsi pendidikan politik, keuangan partai politik. ${ }^{158}$ Terhadap AD partai politik sedikitnya memuat yaitu:159 asas dan ciri Partai Politik, visi dan misi Partai Politik, nama, lambang, dan tanda gambar Partai Politik, tujuan dan fungsi Partai Politik, organisasi, tempat kedudukan, dan pengambilan keputusan, kepengurusan Partai Politik, mekanisme rekrutmen keanggotaan Partai Politik dan jabatan politik, sistem kaderisasi, mekanisme

158 Lihat : Pasal 1 ayat 1-5 UU RI No. 2 Tahun 2011 Tentang Perubahan Atas UU No. 2 Tahun 2008 Tentang Partai Politik

159 Lihat : Pasal 2 Ayat (4) UU RI No. 2 Tahun 2011 Tentang Perubahan Atas UU No. 2 Tahun 2008 Tentang Partai Politik 
pemberhentian anggota Partai Politik, peraturan dan keputusan Partai Politik, pendidikan politik, keuangan Partai Politik; dan mekanisme penyelesaian perselisihan internal Partai Politik.

Tabel II. Mekanisme rekrutmen calon anggota DPR berdasarkan AD/ART

Partai Politik

\begin{tabular}{|c|c|c|c|}
\hline No & $\begin{array}{l}\text { Partai } \\
\text { Politik }\end{array}$ & Mekanisme Rekrutmen & Sifat Rekrutmen \\
\hline 1 & Demokrat & $\begin{array}{ll}\text { WNI; } & \text { Anggota-Parpol;160 Keputusan- } \\
\text { MTP;161 } & \text { Dilaksanakan -DPP162 }\end{array}$ & $\begin{array}{l}\text { Tertutup oleh } \\
\text { Majelis Tinggi }{ }^{163}\end{array}$ \\
\hline 2 & PKS & $\begin{array}{l}\text { Anggota;164 pendukung, inti, kehor- } \\
\text { matan; }{ }^{165} \text { Melegalisir calon-calon MPP }\end{array}$ & Tertutup DPP ke MPP \\
\hline 3 & PDI & $\begin{array}{l}\text { Kader; Mekanisme demokratis untuk } \\
\text { Jabatan Publik Memperhatikan kesetaraan } \\
\text { gender } 167\end{array}$ & Tertutup; ada mekanisme \\
\hline 4 & Nasdem & Anggota; Kader & $\begin{array}{l}\text { Terbuka AD/ART, } \\
\text { Tertutup (DPP) } 168\end{array}$ \\
\hline 5 & PBB & $\begin{array}{l}\text { Keaggotaan; } \quad \text { Kader; } \quad \text { Rekomendasi; } \\
\text { Permohonan }\end{array}$ & $\begin{array}{l}\text { Tertutup (Re-komendasi } \\
\text { Partai) tidak diatur dalam } \\
\text { AD/ART169 }\end{array}$ \\
\hline 6. & PAN & $\begin{array}{l}\text { Keaggotaan; Objektif; } \\
\text { Keterwakilan perempuan }\end{array}$ & Terbuka (Rapat Pleno) $)^{170}$ \\
\hline 7 & Gerindra & Keanggotaan; Diklat; Kader ${ }^{171}$ & Terbuka (AD/ART) \\
\hline 8 & Golkar & $\begin{array}{l}\text { Anggota; Menerima Doktrin; } \text { Meng- } \\
\text { ucapkan Ikrar; pensiunan TNI; POLRI; } \\
\text { PNS }\end{array}$ & $\begin{array}{l}\text { Tidak diatur dalam } \\
\text { AD/ART adanya di } \mathrm{PO}^{172}\end{array}$ \\
\hline 9 & PPP & Mekanisme tidak diatur & Tertutup \\
\hline 10 & PKB & $\begin{array}{l}\text { Keaggotaan; pendaftaran; seleksi } \\
\text { administratif; diumumkan untuk publik }\end{array}$ & $\begin{array}{l}\text { Terbuka dibentuk "tim } \\
\text { mantap" } 173\end{array}$ \\
\hline 11 & Hanura & $\begin{array}{l}\text { Wadah rekrutmen; Kesetaraan gender; } \\
\text { DPP sebagai Penetapan Caleg174 }\end{array}$ & Terbuka dalam AD/ART \\
\hline 12 & PKPI & Mekanisme Tidak diatur & Tertutup \\
\hline
\end{tabular}

Sumber: Diolah dari AD/ART Partai politik Tahun 2014

160 Lihat : Pasal 11 ayat (1) dan (2) AD Partai Demokrat

161 Lihat: Pasal 13 ayat (5) huruf d AD Partai Demokrat

162 Lihat: Pasal 13 ayat (6) AD Partai Demokrat

163 Lihat: Pasal 13 ayat (1) AD Partai Demokrat

164 Lihat: Paal 3 AD Partai PKS

165 Lihat: Pasal 5 ART Partai PKS

166 Lihat: Pasal 9 ART Partai PKS

167 Lihat: Pasal 9 AD PArtai PDI

168 Lihat: Pasal 16 huruf $f$ ART Partai Nasedem

169 Lihat: Pasal 39 ART PBB

170 Lihat : Pasal 26, 27, 28, 29 BAB XIII Penempatan Kader Dan Pengisian Jabatan Publik AD Partai PAN.

171 Lihat: Pasal 14 ayat (4) huruf a AD Gerindra

172 Keputusan Nomor 143/ DPP/Golkar/II/2007 yang berisikan pemantapan orientasi dan perbaikan kriteria, prosedur dan tata cara rekrutmen anggota DPR

173 Lihat: BAB V, Pasal 5 Dan Pasal 6, Peraturan Partai Nomor 02 Tahun 2008.

174 Pasal 32 huruf $k$ dan 1 AD Partai Hanura 
Jika mengacu pada mekanisme rekrutmen dibeberapa konstitusi negara, maka untuk menwujudkan anggota DPR yang aspiratif maka paling tidak beberapa point yang harus diatur dalam undang undang partai politik, diantaranya:

- Adanya mekanisme rekrutmen calon anggota DPR yang tegas di dalam undang undang partai politik untuk dilaksankan oleh partai politik.

- Adanya pengaturan mengenai survey yang dilakukan oleh partai politik untuk mengetahui popularitas individu (calon).

- Adanya pengaturan mengenai lama tinggal dalam daerah distrik sebelum menjadi calon anggota DPR.

- Adanya pengaturan mengenai calon yang loyalis partai politik, yang parameternya dalah lamanya menjadi pengurus partai politik.

- Adanya pengaturan mengenai pembatasan kelompok atau profesi tertentu oleh partai politik untuk diusulkan sebagai calon anggota DPR.

\section{Syarat Anggota Parlemen dibeberapa negara}

Konstitusi di beberapa Negara menunjukkan bahwa penentuan calon anggota Legislatif di tentukan dalam konstitusi negara masing-masing. Sedangkan, Negara Indonesia tidak menunjukkan adanya penentuan syarat calon anggota DPR di dalam konstitusi, hanya ditentukan dalam undang undang (aturan di bawah UUD). Seharusnya peraturan mengenai syarat sebagai calon anggota legislatif diatur dalam UUD, sebab dengan mencantumkannya di dalam UUD maka dapat memberikan kepastian hukum dalam konstitusi. Dan memilki legalitas dan legitimasi kuat ketimbangan hanya diatur di dalam peraturan yang lebih rendah (Undang Undang).

Pada dasarnya, berbagai kesamaan dan perbedaan syarat (Lihat Tabel III). Secara umum persamaan adalah mengatur pada tataran adanya syarat Usia untuk menjadi calon anggota legislatif, sedangkan perbedaannya adalah tidak adanya ukuran kesaman jumlah usia yang dapat menjadi syarat anggota legislatif. Selain dari pada itu juga persamaannya calon anggota legislatif adalah harus warganegara. Sedangkan perbedaanya syarat dan ketentuan yang dimaksudkan pada kewarganegaraan adalah pada tingkat lamanya tinggal di daerah (distrik) mereka di calonkan.

Sebagaimana Calon anggota legislatif (Chamber of Deputies) Negara Itali adalah warganegara Itali, dengan Usia minimal 25 Tahun saat hari pencoblosan, sedangkan asal muasal mereka adalah berasal dari daerah (distrik) yakni:

a) Eropa (termasuk seluruh Federasi Rusia dan Turki);

b) Amerika Selatan;

c) Utara dan Amerika Tengah; dan

d) Afrika, Asia, Oceania dan Antartika

Guna mengetahui ketentuan syarat anggota DPR di beberapa negara sebagaimana Tabel III di bawah ini: 
Tabel III. Ketentuan Syarat rekrutmen calon anggota parlemen dibeberapa Negara

\begin{tabular}{|c|c|c|}
\hline No & Negara & Syarat calon anggota parlemen di beberapa negara \\
\hline 1. & Chile & 35 Tahun; Warga Negara; bersama konstituen 3 thn \\
\hline 2 & Iran & $\begin{array}{l}\text { Warga Negara; sehat penglihatan, pendengaran dan bicara; } \\
\text { usia: 26-75; setia pada Konstitusi; Bukan pemilik tanah besar; } \\
\text { Bukan kelompok illegal; Tidak dihukum karena Negara atau } \\
\text { kemurtadan; tidak pecandu narkoba }\end{array}$ \\
\hline 3 & Brasil & Warga Negara ; bersama konstituen Min. 1 thn; Berusia 21 \\
\hline 4 & Jerman & Usia 18; Warga Negara; Bukan menteri, Auditor, Hakim, PNS. \\
\hline 5 & Italia & Usia 25; Warga Negara \\
\hline 6 & Thailand & $\begin{array}{l}\text { Usia 25; Warga Negara; pemilih } 5 \text { thn; bersama konstituen min. } 5 \\
\text { Thn; anggota Parpol; sebagai pemilih; Bukan PNS, Senat, pemda, } \\
\text { peradilan, lembaga independen }\end{array}$ \\
\hline 7 & USA & $\begin{array}{l}\text { Usia: 25; Warga Negara selama } 7 \text { Tahun; tinggal di Negara yang } \\
\text { mereka wakili. }\end{array}$ \\
\hline 8 & Singapore & $\begin{array}{l}\text { Usia 21; Warga Negara minimal } 10 \text { Tahun; Tidak lumpuh, buta } \\
\text { atau cacat lainnya; Bukan direktur perusahaan; Tidak Pailit; } \\
\text { tidak dipenjara kurang } 1 \text { Tahun; denda tidak kurang } \$ 2.000 \text {; } \\
\text { belum menerima pengampunan gratis; waras }\end{array}$ \\
\hline 9 & Indonesia 176 & $\begin{array}{l}\text { Usia 21; Setia Pancasila, UUD, dan cita-cita Proklamasi; Sehat } \\
\text { jasmani/rohani; sebagai pemilih; Tidak dipenjara } 5 \text { Tahun; } \\
\text { bekerja penuh waktu; bukan PNS, TNI,POLRI, direksi, } \\
\text { komisaris, dewan pengawas dan karyawan BUMN, BUMD atau } \\
\text { badan dari keuangan negara, tidak berpraktik akuntan publik, } \\
\text { pengacara, notaris, (PPAT), }\end{array}$ \\
\hline
\end{tabular}

Sumber: Konstitusi beberapa Negara diolah (2014)

Negara Indonesia, oleh karena tidak adanya kententuan yang mengatur lamanya tinggal di daerah (distrik), tentunya calon DPR akan mudah untuk berpindah - pindah distrik, dengan demikian maka cenderung calon anggota DPR tidak dikenali oleh konstituennya pada disrik masing-masing, calon angggota legislatif tersebut tidaklah aspiratif. Berdasarkan pengamatan penulis dengan memisalkan adanya warga pada Provinsi Sulawesi Selatan namun karena ia menjadi pejabat publik di Ibukota Negara (Jakarta) maka begitu lepas jabatan dan memenuhi syarat administrasi mereka menjadi calon anggota DPR pada distrik Jakarta. Sedangkan, sesungguhnya dia adalah warga Sulawesi Selatan yang patutnya menjadi calon pada distrik Sulawesi Selatan.

Sebagaimana pada Negara Chile bahwa Usia adalah yang dapat menjadi calon anggota legislatif di Negara Chile adalah mereka yang umurnya telah 35 Tahun saat pemilihan dengan ketentuan ia adalah

176 Lihat : Pasal 51 Undang-Undang Nomor 8 Tahun 2012, BAB VII, bagian kesatu tentang persyaratan bakal calon anggota DPR, DPRD Provinsi, dan DPRD Kabupaten/Kota. 
memprediksi perilakunya dalam situasi dan pekerjaan yang lebih luas. Sedangkan criterion - referenced berarti kompetensi seseorang dapat memprediksi apakah kinerjanya baik atau jelek. 188

Spencer dalam buku Competence at work, models for superior performance. Tahun 1992 juga memberikan 5 (lima) karakteristik dasar dari kompetensi, yaitu:

a. Motif (motive). Sesuatu yang secara terus menerus dipikirkan atau diinginkan oleh seseorang yang menyebabkan adanya tindakan. Motif ini 'menggerakkan, mengarahkan dan memilih' perilaku terhadap tindakan tertentu atau tujuan dan berbeda dari orang lainnya.

b. Sifat (traits). Karakteristik fisik dan respon yang konsisten terhadap situasi dan informasi.

c. Konsep pribadi (self-concept)/Perilaku, nilai - nilai dan kesan pribadi seseorang.

d. Pengetahuan (knowledge). Informasi mengenai seseorang yang memiliki bidang substansi tertentu.

e. Keterampilan (skill). Kemampuan untuk melaksanakan tugas fisik dan mental tertentu. 189

Rothwell dalam buku Models of human performance improvement Tahun $2000^{190}$ mengidentifikasi kompetensi yang dibutuhkan seseorang dalam melaksanakan tugas dan tanggungjawabnya meliputi technical competence, managerial competence, interpersonal competence (social/communication competence) dan intellectual competence (strategic competence). Dari beberapa pendapat mengenai kompetensi tersebut dapat dikatakan bahwa kompetensi yang dibutuhkan oleh seseorang dalam suatu organisasi adalah:

a. Technical competence. Kompetensi teknik dalam prakteknya adalah bersifat ketrampilan dan kemampuan khusus yang diperlukan untuk melaksanakan tugas- tugasnya.

b. Managerial competence. Kompetensi ini berkaitan dengan kemampuan manajerial dalam hal perencanaan, pengorganisasian, penggerakkan dan pengawasan.

c. Social competence. Kompetensi soial adalah kemampuan seseorang dalam berinteraksi dengan pihak lain.

d. Strategic competence. Kompetensi strategic adalah kemampuan melihat jauh ke depan sehingga dapat merumuskan berbagai kebijakan yang sifatnya strategis.

e. Ethical competence. Kompetensi etika adalah kemampuan untuk melaksanakan tugas dan tanggungjawabnya dengan pertimbangan etika dan moral.

188 Ibid. Hal : 60

189 Ibid. Hal : 61

190 Ibidi. Hal : 61 
Penguatan kompetensi calon anggota DPR adalah penguatan yang dilakukan oleh partai politik sebagai lembaga yang melaksanakan pendidikan bagi kader partai politik sebagaimana diamanatkan dalam undang undang partai politik. Sebagaimana Pasal 1 Ayat 4 Undang Undang No. 2 Tahun 2011 tentang Partai Politik bahwa "Pendidikan Politik adalah proses pembelajaran dan pemahaman tentang hak, kewajiban, dan tanggung jawab setiap warga negara dalam kehidupan berbangsa dan bernegara".

Partai politik penting untuk memberikan pendidikan bagi kader dalam memahamai aspek hak dan kewajiban warganegara di dalam kehidupan berbangsa dan bernegara. Terkhusus pada penguatan sebagai calon anggota DPR maka penguatan kemampuan untuk memahami tugas, peran dan anggota DPR.

Perlu ada penguatan calon anggota DPR, yang bukan hanya kemampuan untuk memahami situasi dan kondisi masyarakat yang diwakili, namun juga adalah kemampuan untuk membawa aspirasi hingga menuangkannya dalam regulasi sebagaimana tugasnya sebagai anggota DPR. Sebagai perbandingan kompetensi dengan beberapa negara sebagaimana diuraikan dalam Tabel IV.

Tabel IV. Kompetensi calon anggota parlemen di beberapa Negara.

\begin{tabular}{|c|c|c|}
\hline No. & Negara & Kompetensi calon anggota parlemen \\
\hline 1. & Chile & - Pendidikan menengah \\
\hline 2. & Iran & $\begin{array}{l}\text { - } \text { Pendidikan minimal S2 } \\
\text { - } \text { Berkelakuan baik } \\
\text { - } \text { Memahami soal pemilu } \\
\text { - Keaksaraan yang memadai }\end{array}$ \\
\hline 3. & Brasil & - Tidak buta huruf \\
\hline 4. & Jerman & - Berprestasi luar dapat meniti karier di Budestag \\
\hline 5. & Italia & $\begin{array}{l}\text { - kapasitas tertentu dipekerja-kan eksekutif, admin-istrasi publik } \\
\text { (BUMN) dalam sektor ekonomi. }\end{array}$ \\
\hline 6. & Thailand & $\begin{array}{l}\text { - } \text { Berpendidikan } \\
\text { - Tidak ke canduan obat. } \\
\text { - } 5 \text { Tahak bangkrut. } \\
\text { - Tidak terlibat korupsi } \\
\text { - Tidak pernah terlibat dalam penggelapan }\end{array}$ \\
\hline 7. & USA & - Ada pelatihan untuk anggota parlemen \\
\hline 8. & Singapore & $\begin{array}{l}\text { - Kemampuan bidang parlemen } \\
\text { - Mampu bicara } \\
\text { - Mampu membaca menulis salah dari bahasa Inggris, Melayu, } \\
\text { Mandarin, dan Tamil }\end{array}$ \\
\hline 9. & Indonesia 191 & $\begin{array}{l}\text { - berbicara, membaca, dan menulis bahasa Indonesia } \\
\text { - Minimal SMA. }\end{array}$ \\
\hline
\end{tabular}

Sumber: Konstitusi dibeberapa Negara diolah (2014)

191 Lihat : Pasal 51 Undang-Undang Nomor 8 Tahun 2012, BAB VII, bagian kesatu tentang persyaratan bakal calon anggota DPR, DPRD Provinsi, dan DPRD Kabupaten/Kota. 
pelanggaran norma-norma masyarakat, norma agama, dan norma etika. Hal tersebut tentu peran penting partai politik untuk mengetahui setiap anggota partai politik, untuk dapat dijadikan sebagai calon untuk dipilih oleh masyarakat.

Sebagaimana diamanahkan di dalam peraturan perundang undangan negara Indonesia, mengharuskan adanya pendidikan politik, sebagaimana dalam ketentuan umum bahwa:

“..... Kedua, memaksimalkan fungsi Partai Politik baik fungsi Partai Politik terhadap negara maupun fungsi Partai Politik terhadap rakyat melalui pendidikan politik dan pengkaderan serta rekrutmen politik yang efektif untuk menghasilkan kader-kader calon pemimpin yang memiliki kemampuan di bidang politik." 193

Sedangkan pendidikan politik dimaksudkan pada Pasal 1 Ayat 4 bahwa:

"Pendidikan Politik adalah proses pembelajaran dan pemahaman tentang hak, kewajiban, dan tanggung jawab setiap warga negara dalam kehidupan berbangsa dan bernegara."

Sedangkan Pasal 34 (3b) pendidikan politik berkaitan dengan kegiatan:

a. pendalaman mengenai empat pilar berbangsa dan bernegara yaitu Pancasila, UUD 1945, Bhinneka Tunggal Ika dan Negara Kesatuan Republik Indonesia;

b. pemahaman mengenai hak dan kewajiban warga negara Indonesia dalam membangun etika dan budaya politik; dan

c. pengkaderan anggota Partai Politik secara berjenjang dan berkelanjutan.

Amanah Undang Undang Partai Politik menghendaki adanya pelaksanaan fungsi partai politik yang dilaksanakan dalam bentuk pendidikan anggota partai politik. Hal ini dimaksudkan adalah adanya persiapan untuk menjadi pemimpin bangsa. Jika hal tersebut dilaksanakan oleh partai politik maka partai politik ideal untuk menjadi bagian dalam pembangunan sumber daya manusia guna melahirkan kader yang dapat diharapkan menjadi pemimpian Negara kelak. Namun demikian, hal tersebut harus tercantum di dalam AD/ART.

Partai politik sebagai dasar dan pedoman umum bukan hanya untuk anggota partai politik namun juga masyarakat secara umum. Maka sebagai langkah kongret yang dilakukan oleh partai politik adalah melakukan perkaderan bagi anggota partai politiknya, dan ketentuannya harus dimuat dalam AD/ART masing masing partai politik, demikian kehendak dari ketentun undang undangan partai politik, dan konsep partai politik yang ideal diterapkan pada Negara yang menganut demokrasi seperti Negara Indonesia.

Pendidikan politik merupakan bagian dari proses penguatan bagi calon anggota DPR, yang materi pengaturannya dimuat dalam aturan partai politik. Hal tersebut dapat dilihat pada Tabel V:

193 Lihat : Pasal 2 ayat (4) huruf k Undang-Undang Republik Indonesia Nomor 2 Tahun 2011 Tentang Perubahan Atas Undang-Undang Nomor 2 Tahun 2008 Tentang Partai Politik. 
Tabel V : Penguatan kompetensi calon anggota DPR oleh Partai Politik

\begin{tabular}{cll}
\hline No. & Partai Politik & Pendidikan Politik Penguatan Kompetensi Calon Anggota DPR \\
\hline 1. & PKB & Mengikuti uji kompetensi; Diklat \\
\hline 2 & Golkar & Klasifikasi kompetensi kader kader \\
3 & Gerindra & Diklatsus \\
4. & PAN & Perkaderan \\
5. & PBB & Pelatihan \\
6. & Nasdem & Perkaderan berjenjang \\
7. & PKS & Pelatihan berjenjang; Pembinaan \\
8. & PDI & tidak ditemukan \\
\hline 9. & PPP & Pendidikan; Penataran; Bimbingan \\
11. & Hanura & Perkaderan; Penguatan kelompok profesi \\
\hline 11. & Demokrat & Tidak ditemukan \\
\hline 12. & PKPI & Proses pendidikan dan pelatihan kader partai. \\
\hline
\end{tabular}

Sumber : AD/ART Partai Politik di Indonesia, Diolah 2014

Sebagaimana pada gambaran Tabel $\mathrm{V}$ di atas bahwa dengan berdasar pada ketentuan Undang Undang Undang Undang No. 2 Tahun 2011 tentang Partai Politik hubungannya dengan pelaksanaan pendidikan pada masingmasing partai politik, dapat dilihat uraian di bawah ini.

Partai Demokrat dalam melakukan pembinaan terhadap anggota adalah melibatkan anggota sendiri sebagai pelaksana, Maka partai memberikan penguatan kepada anggota dengan berdasarkan undang undang dan peraturan organisasi.

Sedangkan AD/ART Partai PKPI bahwa:194

(1) Kader partai adalah anggota partai sebagai tenaga inti penggerak organisasi di setiap tingkatan partai yang telah diteliti dan disaring berdasarkan kriteria :

a. Mental ideologi kebangsaan Indonesia dalam bingkai NKRI berdasarkan Pancasila dan UUD 1945;

b. Prestasi;

c. Dedikasi;

d. Loyalitas dan ketaatan pada keputusan partai;

e. Kepemimpinan;

f Kemandirian;

g. Kemampuan pengembangan diri;

h. Telah melalui proses pendidikan dan pelatihan kader partai.

(2) Ketentuan tentang jenjang kader PKP Indonesia diatur dalam Peraturan Partai.

Sebelum melaksanakan rekrutmen upaya yang dilakukan Partai Hanura adalah melakukan pendidikan politik sebagaimana Pasal 23 Ayat (1) dan (2) AD Partai Hanura bahwa:

(1) Partai Politik melakukan pendidikan politik bagi masyarakat sesuai

194 Lihat: Pasal 9 ayat (1) dan (2) Anggaran Rumah Tangga PKP Indonesia. 
anggota dan masyarakat secara umum pada dasarnya tidak terlaksana secara ideal. Partai Politik cenderung menggunakan tafsiran-tafsiran yang tidak berdasar pada kehendak filosofis fungsi dari partai politik. Partai politik seolah menjadi lembaga yang hanya dikelolah berdasarkan kepentingan dari pengurus, oleh karena tidak adanya korelasi atau kesesuaian cita dasar undang undang terhadap implementasinya pada AD/ART sebagai payung hukum pelaksanaan peran dan fungsi partai politik. 


\section{BAB VII}

STANDAR PEMILU

INTERNASIONAL

\section{A. Pengertian Pemilihan Umum}

Pemilihan umum adalah salah satu syarat berlangsungnya demokrasi. Namun, tidak semua pemilu berlangsung secara demokratis. ${ }^{209}$ Robert A Dahl memberikan ukuran-ukuran yang harus dipenuhi agar suatu pemilihan umum memenuhi prinsip-prinsip demokrasi: Pertama, inclusiveness, artinya setiap orang yang sudah dewasa harus diikutkan dalam pemilu; kedua, equal vote, artinya setiap suara mempunyai hak dan nilai yang sama; ketiga, effective participation, artinya setiap orang mempunyai kebebasan untuk mengekspresikan pilihannya; keempat, enlightened understanding, artinya dalam rangka mengekspresikan pilihan politiknya secara akurat, setiap orang mempunyai pemahaman dan kemampuan yang kuat untuk memutuskan pilihannya; dan kelima, final control of agenda, artinya pemilu dianggap demokratis apabila terdapat ruang untuk mengontrol atau mengawasi jalannya pemilu. ${ }^{210}$

Sekaitan dengan padangan di atas bahwa konsep demokrasi dalam pemilihan umum paling tidak memiliki syarat, bahwa demokrasi hanya berarti jika rakyat punya kesempatan untuk menerima atau menolak orang atau kelompok orang yang memimpinnya. Kesempatan menerima atau menolak tersebut hanya bisa dilakukan lewat pemilihan umum. Karena itu, pemilu sesungguhnya merupakan syarat mutlak (conditio sine qua non) bagi terselenggaranya pemerintahan yang berdasarkan prinsip perwakilan.

\footnotetext{
209 Didik Supriyanto. 2007. Menjaga Independensi Penyelenggara Pemilu, Perludem, Jakarta Hal : 22

210 Robert A Dahl, "Procedural Democracy," dalam P Laslett and J Fishkin (ed). Philosophy. Politics and Society. Fifth Series. New Haven. 1979. Yale University Press. Hal: 97-133.
} 
Sebagaimana pandangan Menurut RH Taylor, ${ }^{211}$ bahwa:

"Karena itu juga, pemilu yang demokratis memerlukan sejumlah persyaratan, yaitu: a) adanya pengakuan terhadap hak pilih universal; b) adanya keleluasaan untuk membentuk tempat penampungan bagi pluralitas aspirasi masyarakat pemilih; c) adanya mekanisme rekrutmen politik bagi calon-calon wakil rakyat yang terbuka; d) adanya kebebasan bagi pemilih untuk mendiskusikan dan menentukan pilihannya; e) adanya keleluasaan bagi peserta pemilu untuk berkompetisi secara sehat; f) adanya penghitungan suara yang dilakukan secara jujur; g) adanya netralitas birokrasi; dan, h) adanya lembaga penyelenggara pemilihan yang independen.

Kegiatan pemilihan umum (general election) juga merupakan salah satu sarana penyaluran hak asasi warga negara yang sangat prinsipil. Oleh karena itu, dalam rangka pelaksanaan hak-hak asasi warga negara adalah keharusan bagi pemerintah untuk menjamin terlaksananya penyelenggaraan pemilihan umum sesuai dengan jadwal ketatanegaraan yang telah ditentukan sebagaimana Menurut Jimly Asshiddiqie ${ }^{212}$

".. Sesuai dengan prinsip kedaulatan rakyat di mana rakyatlah yang berdaulat, maka semua aspek penyelenggaraan pemilihan umum itu sendiri pun harus juga dikembalikan kepada rakyat untuk menentukannya. Adalah pelanggaran terhadap hak-hak asasi apabila pemerintah tidak menjamin terselenggaranya pemilihan umum, memperlambat penyelenggaraan pemilihan umum tanpa per setujuan para wakil rakyat, ataupun tidak melakukan apa apa sehingga pemilihan umum tidak terselenggara sebagaimana mestinya."

Sebagaimana pandangan Harris G. Warren²13, Pemilihan Umum (pemilu) merupakan:

"Elections are the accostions when citizens choose their officials and cecide, what they want the government to do. In making these decisions citizens determine what rights they want to have and keep." (Pemilu merupakan pemberian kesempatan kepada masyaratakat/warganegara dalam rangkan memilih pejabat pemerintah/wakil mereka dan menjadi wadah untuk menetukan kehendak dan keinginan mereka untuk dilaksanakan/dikerjakan oleh pemerintah / wakilnya tersebut di dalam membuatan keputusan.)

Sedangkan pandangan Ali Moertopo ${ }^{214}$ bahwa pada hakikanya pemilihan umum adalah:

"Sarana yang tersedia bagi rakyat untuk menjalankan kedaulatannya sesuai dengan azas yang bermaktub dalam Pembukaan UUD 1945. Pemilu itu sendiri pada dasarnya adalah suatu Lembaga Demokrasi yang memilih anggota-anggota perwakilan rakyat dalam MPR, DPR, DPRD, yang pada gilirannya bertugas

211 RH Taylor, "Election and Politics in Southeast Asia," dalam RH Taylor, 1996. ed, The Politics of election in Southeast Asia, Canbridge: Woodrow Wilson Center Press and Canbrige University Press, Hal :2.

212 Jimly Asshiddiqie 2006. Pengantar Ilmu Hukum Tata Negara. Jilid II. Konstitusi Press. Jakarta. Hal $: 172$.

${ }^{213}$ Harianto, 1998. Partai Politik untuk Tujuan Umum. Liberty. Yogyakarta. Hal :81.

214 Ali Murtopo. 1974. Strategi Politik Nasional. CSIS. Jakarta. Hal : 61 
menggunakan sistem proporsional daftar terbuka dalam arti sebenarnya. Proporsional daftar terbuka berarti pemilih dapat memilih bukan saja partai, tetapi juga caleg dari partai tersebut. 19 Caleg yang memperoleh suara terbanyak ditetapkan menjadi caleg terpilih, tanpa mempedulikan nomor urut.

Mestinya, pengaturannya dilakukan secara konsisten antara pilihan sistem dengan teknis penentuan caleg terpilih. Jika sistemnya proporsional terbuka, maka pemilih mestinya diberi ruang untuk memilih caleg, dan keterpilihan caleg mesti didasarkan pada pilihan tersebut. Sebaliknya, jika sistem yang dipilih adalah proporsional tertutup, maka pemilih memberikan suaranya kepada partai dan keterpilihan caleg diserahkan kepada partai. Dengan sistem ini, berarti pemilih telah memberikan kedaulatannya kepada partai untuk menentukan caleg terpilih. Menentukan sistem pemilihan umum yang tepat, kata kuncinya adalah "Harus dilihat dulu apa pengaruh dari penerapan sesuatu sistem pemilu terhadap prospek pengembangan demokrasi dan memaksimalkan fungsi representasi di lembaga-lembaga perwakilan rakyat".

Untuk saat ini sistem pemilu yang masih relevan adalah tetap kombinasi antara sistem distrik dan sistem perwakilan berimbang seperti yang dikatakan oleh M. Ryaas Rashid. ${ }^{241}$ Hal ini sejalan dengan rekomendasi LIPI, ${ }^{242}$ bahwa sistem pemilu di Indonesia sebaiknya tidak diterapkan sistem proporsional murni maupun sistem distrik murni, tetapi sebaiknya kombinasi dari kedua sistem tersebut dengan memanfaatkan kebaikan masing-masing sistem dan mengeliminasi kelemahan masing-masing. Adapun caranya bisa macammacam, yaitu:

Pertama, menetapkan wilayah pemilihan, tapi jumlah kursi yang diperebutkan dari wilayah itu lebih dari satu. Pada saat yang sama, juga ditetapkan adanya sejumlah kursi di parlemen yang diperebutkan oleh caloncalon partai secara nasional (the nationwide constituency).

Kedua, menetapkan bahwa hasil pemilihan disatu distrik hanya menghasilkan satu wakil dari distrik itu, tapi sisa-sisa suara dari partai yang kalah disemua distrik dihimpun secara nasional untuk kemudian dipakai dalam menetapkan jumlah wakil dari partai yang bersangkutan menurut satuan jumlah suara yang disepakati. Dengan demikian, dua tujuan dapat dicapai, yakni keikatan wakil rakyat dengan konstituennya, dan peluang partai kecil untuk terwakili secara proporsional.

Ketiga, menetapkan daftar nama calon dari tiap-tiap partai yang harus dipilih bersamaan dengan pilihan atas partainya di wilayah tertentu. Proses perhitungan suara terbagi atas dua tahap. (1) Perhitungan atas suara yang masuk untuk partai-partai demi menentukan beberapa kursi yang diperoleh suatu partai di wilayah pemilihan itu; (2) Perhitungan suara untuk masing-

241 M. Ryaas Rashid, . 2000. Fungsi Representasi dan Sistem Pemilu, dalam Sistem-Sistem Pemilu. Badan Penerbit Fakultas Hukum Universitas Indonesia, Jakarta..Hal : 134.

242 Abdul Mukthie Fadjar. 2003. Reformasi Konstitusi Dalam Masa Transisi Paradigmatik. Institute for Strengthening Transition Society Studies (In-TRANS) Malang Hal :101. 
masing calon dalam partai, dimana para calon memperoleh suara terbanyak secara berurutan akan ditetapkan sebagai wakil-wakil partai itu di parlemen.

Pendek kata, setiap sistem selalu mengandung kelebihan dan kelemahannya sendiri-sendiri. Tidak ada yang sempurna di dunia ini. Bahkan, negara-negara yang tadinya menganut sistim distrik cenderung berusaha untuk mengadopsi sistim proporsional, tetapi negara negara yang biasa dengan sistim proporsional dan banyak mengalami sendiri kekurangan kekurangannya, cenderung berusaha untuk menerapkan sistim distrik yang dianggapnya lebih baik. Semua pilihan itu tergantung tingkat kebutuhan riel yang dihadapi setiap masyarakat yang ingin memperkembangkan tradisi dan sistem demokrasi yang diterapkan di masing-masing negara. ${ }^{243}$

243 Jimly Asshiddiqie. 2006. Pengantar Ilmu Hukum Tata Negara. Jilid II. Konstitusi Press. Jakarta. Hal :185. 


\section{BAB VIII PENATAAN HUKUM PEMILU PARLEMEN DI BEBERAPA NEGARA}

K omisi Pemilihan Umum atau KPU sebagai lembaga penyelenggara pemilihan umum yang dilaksanakan secara berdasarkan asas langsung, internasional penyelenggara pemilihan umum untuk menjamin agar lembaga bekerja secara independen, Yaitu berdasarkan pada: Deklarasi Universal Hakhak Asasi Manusia Tahun 1944 dan Kovenan Internasional Hak-hak Sipil dan Politik Tahun 1966. Berdasarkan dua dokumen internasional tersebut, International Parliamentary Union dan IDEA International merumusan sejumlah standar kelembagaan penyelenggara pemilihan umum, yaitu:

Pertama, Independensi penyelenggara pemilu merupakan persoalan penting, karena penyelenggara pemilihan umum membuat dan melaksanakan keputusan yang dapat mempengaruhi hasil pemilihan umum. Oleh karena itu, lembaga tersebut harus bekerja dalam kerangka waktu cukup, memiliki sumberdaya mumpuni, dan tersedia dana memadai.

Kedua, Undang-undang pemilihan umum harus mengatur. ${ }^{244}$ ukuran, komposisi, dan masa kerja anggota lembaga penyelenggara pemilu. Juga mengatur hubungan antara lembaga penyelenggara pemilu pusat dan lembaga-

244 Anonim. (http://www.rumahpemilu.org/in/read/65/Mengapa-Perlu-Standar InternasionalPemiluPenyelengara diakses 23 Mei 2014) 
lembaga pemilu tingkat yang lebih rendah (daerah), serta hubungan antara semua lembaga pemilu dengan lembaga eksekutif. Undang-undang harus membuat ketentuan tentang mekanisme untuk memproses, memutuskan, dan menangani keluhan dalam pemilu secara tepat waktu. Sedangkan standar kompetensi anggota di dalam kelembagaan adalah warganegara yang memiliki kompetensi, yang diberikan tugas dan fungsi sehingga penyelenggaraan pemilihan umum dapat menjawab amanat konstitusi, terhadap lembaga penyelenggara pemilihan umum yang tetap dan mandiri.

Dari kedua bagian tersebut harusnya diatur dalam suatu aturan perundang undangan untuk menjadikan hukum dasar penyelenggaraan pemilihan umum. Terkait dengan kompetensi penyelenggara sebagaimana dirincikan berikut di bawah ini;

a. Hubungan kewenangan, adanya undang undang yang mengatur wewenang dan atau tugas antara penyelenggara tingkat nasional, Provinsi dan Kabupaten/Kota, pengaturan hubungan kewenangan masing-masing tingkatan penyelenggara pemilihan umum secara vertikal, dan hubungan kewenangan baik kerjasama maupun control/pengawasan terhadap lembaga negara lain secara horizontal.

b. Kualifikasi anggota penyelenggara pemilihan umum, bahwa yang dapat menjadi anggota penyelenggara pemilihan umum adalah warganegara yang memiliki kualifikasi dan professional dibidang kepemiluan. Paling tidak memiliki integritas, profesional, dan akuntabilitas. Unsur tersebut dapat ditemukan pada tokoh masyarakat, anggota hakim/pensiunan Hakim, akademisi, LSM, dan pers.

c. Terhadap independensi anggota penyelenggara pemilihan umum, bahwa penyelenggara pemilihan umum harus tidak terpengaruh dari pihak manapun baik secara politik atau secara sosial di dalam penyelenggaraan pemilihan umum. Penyelenggara pemilihan umum hanya tunduk pada suatu peraturan dan sebagai amanat konstitusi.

d. Mekanisme rekrutmennya dilakukan secara ketat untuk menyaring kompetensi, sehingga yang dipilih menjadi anggota penyelenggaara pamilihan umum adalah mampu menjalankan tugas dan wewenangnya sebagaimana amanah konstitusi. Mekanisme dan kompetensi harus dilakukan secara transparan berdasarkan standar kemampuan masingmasing. Serta, Pihak yang melaksanakan seleksi adalah memahami track record dari masing-masing calon anggota penyelenggara pemilihan umum, termasuk kesehatan, keilmuan (standak akademik), pengalaman, dan kredibilitas, serta independensinya.

Penyelenggara pemilihan umum menjadi bagian penting dalam mewujudkan demokrasi dengan berdasar pada konstitusi, sebagaimana dalam alinea ke-IV Pembukaan UUD NRI 1945 bahwa "Kerakyatan yang dipimpin oleh hikmat kebijaksanaan dalam permusyawaratan/perwakilan." pada alinea tersebut menjadi dasar dalam melaksanakan demokrasi di Indonesia dengan 
Quran Surah Al Isra (17: 36), 253 yang artinya bahwa :

"Dan janganlah kamu mengikuti apa yang kamu tidak mempunyai pengetahuan tentangnya. Sesungguhnya pendengaran, penglihatan dan hati, semuanya itu akan diminta pertanggung jawabnya."

Sebagai turunan (aturan organil) dari ayat tersebut di atas, sebagaimana Rasulullah SAW. Berkata:

"Apabila suatu urusan diserahkan kepada yang bukan ahlinya, maka tunggulah saat kehancuran." (Hadist Bukhari).

Indikator Profesionalitas, berdasarkan Ayat dan Hadits tersebut di atas, ditafsirkan bahwa unsur profesionalitas sebagai berikut;

1. Kejujuran (shiddiq).

2. Tanggung jawab (amanat).

3. Transparan/ komunikatif (tabligh).

4. Pengetahaun/cerdas (fathanah).

Hubungannya dengan Tugas dan wewenang KPU sebagai penyelenggara pemilihan umum begitu luas yang mengatur mulai dari tahapan-tahapan pelaksanaan pemilihan umum (electoral regulation), melaksanakan seluruh tahapan proses pemilihan umum (electoral process), dan mengawasi serta menegakkan peraturan pelaksanaan pemilihan umum (electoral law enforcement). ${ }^{254}$ Sehingga diperlukan adanya anggota KPU yang bekerja secara professional.

Terhadap tugas dan wewenang KPU yang begitu kompleks sehingga menjadi keharusan penyelenggara pemilihan umum anggota KPU, memiliki; kejujuran (shiddiq), Tanggung jawab (amanat), Transparan/ komunikatif (tabligh), Pengetahaun / cerdas (fathanah).

Dengan demikian, Syarat profesionalitas harus tertuang dalam peraturan perundang undangan sebagai ketentuan dasar pelaksanaan rekrutmen calon anggota KPU. Selain menjadi syarat, untuk efektivitas profesionalitas, maka adanya unsur profesionalitas yang tertuang dan diatur dalam ketentuan hokum yang berlaku untuk melaksanakan rekrutmen calon anggota KPU.

\section{B. Penyelenggara pemilihan umum di beberapa Negara}

Mewujudkan profesionalitas penyelenggara pemilihan umum diperlukan adanya mekanisme yang dapat mengukur profesionalitas dari pada penyelenggara pemilihan umum. Bahwa dengan adanya mekanisme yang dilakukan dimaksudkan dapat mengukur sejauhmana kemampuan (kompetensi) penyelenggara pemilu., Selanjutnya, diperlukan adanya pengawasan terhadap penyelenggara Pemilihan umum. Untuk itu, sebagai perbandingan dengan beberapa negara dalam melaksankaan rekrutmen; (pencalonan, pemilihan dan pengangkatan) terhadap lembaga penyelenggara

253 Lihat: . Al-Qur'an Surah Al-Isra $17: 36$

254 Tauchid Noor. 2009. Peran Komisi Pemilihan Umum Meningkatkan Partisipasi Masyarakat Dalam Pemilihan Umum. Jurnal Konstitusi. Vol. ii. No. 1. Juni. Hal : 53 
pemilihan, sebagaimana tugas masing-masing pada Negara Afirika Selatan, India, Meksico, Thailan, Korea Selatan, Australia, dan Indonesia. Sebagaimana diuraikan pada tabel VI di bawah ini:

Tabel VI. Mekanisme Rekrutmen Penyelenggara Pemilihan Umum Di Beberapa Negara

\begin{tabular}{|c|c|c|}
\hline No & Negara & $\begin{array}{c}\text { Pencalonan Pemilihan \& } \\
\text { Pengangkatan Penyelenggara Pemilu }\end{array}$ \\
\hline 1 & Afrika Selatan & $\begin{array}{l}\text { - } \text { Majelis Nasional mencalonkan nama kepada Komite Panel. } \\
\text { - Komite Panel (Presiden, Ketua Mahkamah Konstitusi, wakil Komisi } \\
\text { HAM, wakil Komisi Penyetaraan Gender dan Perlindungan Publik) } \\
\text { merekomendasikan kepada Presiden } \\
\text { - Presiden atau Perdana Menteri mengangkat Anggota Komisi Pemilu. }\end{array}$ \\
\hline 2 & India & - Presiden menunjuk dan mengangkat Anggota Komisi Pemilu \\
\hline 3 & Meksico & $\begin{array}{l}\text { - Majelis Rendah memilih } 9 \text { (Sembilan) anggota; Majelis Tinggi memilih } \\
12 \text { anggota dari partai dan seorang Sekretaris Eksekutif. }\end{array}$ \\
\hline 4 & Thailand & $\begin{array}{l}\text { - Komite Seleksi terdiri dari wakil partai } \\
\text { 1. Majelis Rendah dan } 10 \text { orang yang terdiri atas Ketua Mahkamah } \\
\text { Konstitusi, } \\
\text { 2. Ketua Pengadilan Administrasi Tinggi, } \\
\text { 3. Para Rektor Perguruan Tinggi } \\
\text { - Komite seleksi memilih } 8 \text { orang dari antara mereka sendiri untuk } \\
\text { diajukan ke Senat. } \\
\text { - Jika Senat setuju, Mahkamah Agung akan memilih } 5 \text { orang untuk } \\
\text { diajukan kembali ke Senat. } \\
\text { - Jika dalam waktu yang ditentukan Komite Seleksi tidak dapat } \\
\text { menetapkan nama tersebut, maka Mahkamah Agung harus } \\
\text { melengkapinya. }\end{array}$ \\
\hline 5 & Korea & $\begin{array}{l}\text { Presiden, Parlemen dan Mahkamah Agung masing-masing Menunjuk } \\
\text { sepertiga Anggota Komisi Pemilu. }\end{array}$ \\
\hline 6 & Inggris & $\begin{array}{l}\text { - Commissioner The Electoral Commission ditetapkan oleh Ratu atas usul } \\
\text { House of Commons } \\
\text { - Dapat diberhentikan jabatannya oleh Ratu juga atas usul House of } \\
\text { Commons. }\end{array}$ \\
\hline 7 & Indonesia & $\begin{array}{l}\text { - Pemerintah membentuk tim seleksi KPU terdiri atas akademisi, } \\
\text { profesional dan masyarakat. } \\
\text { - Tim seleksi secara terbuka mengumumkan kepada masyarakat tentang } \\
\text { pendaftaran calon, persyaratan, dan batasan waktu. } \\
\text { - } \text { Adanya tahapan persyaratan administrasi } \\
\text { - Mengikuti ujian tertulis dan wawancara. } \\
\text { - Tim Seleksi menetapkan nama-nama yang lulus sebanyak tiga kali } \\
\text { lipat dari jumlah yang diperlukan, } \\
\text { - Memperhatikan 30\% calon perempuan. } \\
\text { - Nama-nama diajukan ke Presiden. } \\
\text { - Tim Seleksi langsung dikirim ke DPR untuk uji kelayakan dan } \\
\text { kepatutan (fit and proper test). } \\
\text { - DPR memilih } 7 \text { (tujuh) orang kemudian diserahkan ke Presiden untuk } \\
\text { diangkat. } \\
\text { - Presiden mengeluarkan Keputusan Presiden (Kepres) tentang } \\
\text { pengangkatan anggota KPU. }\end{array}$ \\
\hline
\end{tabular}

Sumber: Cetro ${ }^{255}$ Diolah pada 9 Agustus 2014

255 Didik Supriayanto. 2007. Menjaga Independensi Penyelenggara Pemilu. USAID. Jakarta. Hal : 29-33 
memiliki potensi dan kemampuan yang memancarkan kewibawaan; kejujuran (nomina). Sedangkan National Integrity Plan (NIP) Malaysia, integritas secara umum adalah quality of exellence yang termanifestasikan dalam sikap yang terintegrasi dan holistik secara individual maupun organisasi. 264

Menurut Herb Shepherd ${ }^{265}$ menyebutkan integritas diri sebagai kesatuan yang mencakup empat nilai, yaitu perspektif (spiritual), otonomi (mental), keterkaitan sosial, dan tonus (fisik). George Sheehan menjabarkan integritas diri sebagai kesatuan empat peran, yaitu menjadi binatang yang baik (fisik), ahli pertukangan yang baik (mental), teman yang baik (sosial), dan orang suci (spiritual). Menurut Antonius Atosokhi Kedua tokoh itu, walau dengan istilah yang agak berbeda, namun sama-sama menyebutkan hal yang merupakan unsur penting dalam diri manusia, yakni fisik, sosial, dan mental-spiritual.

Seorang pribadi yang memiliki integritas, dalam dirinya terdapat ciri-ciri berikut: Pertama, ia memiliki fisik yang sehat dan bugar, memiliki kemampuan hidup sosial yang semakin baik, memiliki kekayaan rohani yang semakin mendalam, dan memiliki mental yang kuat dan sehat; Kedua, kadar konflik dirinya rendah. Ia tidak berperang melawan dirinya sendiri (pribadinya menyatu). Dengan demikian, dia memiliki lebih banyak energi untuk tujuan produktif; Ketiga, memiliki kemampuan dalam menata batin sampai mencapai tahap kebebasan batin dalam arti tidak mudah diombang-ambing oleh gejolak emosi dan perasaan sendiri; Keempat, semakin memiliki cinta yang personal/kedekatan hidup pada Tuhan sehingga mampu menanggung risiko dan konsekuensi dari pilihan hidup religiusnya; Kelima, seorang yang tidak mudah binggung tentang mana yang benar atau salah, baik atau buruk, demikian pula persepsinya tentang tingkah laku yang benar tidak mengalami banyak keraguan; Keenam, seseorang yang memiliki kemampuan melihat hidup secara jernih, melihat hidup apa adanya, dan bukan menurut keinginannya. Seseorang tidak lagi bersikap emosional, melainkan bersikap lebih objektif terhadap hasil pengamatannya; Ketujuh, orang ini juga dapat membaktikan tugas, kewajiban atau panggilan tertentu yang ia pandang penting. Karena berminat pada pekerjaannya itu, ia bekerja keras. Baginya, bekerja memberikan kegembiraan dan kenikmatan. Rasa bertanggung jawab atas tugas penting merupakan syarat utama bagi pertumbuhan, aktualisasi diri, serta kebahagiaan.

Integritas diri merupakan penilaian yang diberikan oleh orang lain, berupa pengakuan dari apa yang mereka lihat dan alami. Hal itu tampak dari sikap konsisten yang selalu muncul dalam berbagai sikap, perkataan, dan tindakan. Orang yang memiliki integritas diri dapat menjadi inspirasi positif bagi orang disekitarnya, berikut (Tabel VII) terkait integritas Pemilu di beberapa Negara.

264 Integrity Institute of Malaysia, National Integrity Plan, 23 April 2004

265 Antonius Atosökhi 2006. Gea integritas diri: Keunggulan pribadi tangguh. Character Building Journal. Vol. 3 No. 1. Juli Jakarta. Hal. :17 
Tabel VII. Integritas Penyelenggara Pemilihan Umum Di Beberapa Negara

\begin{tabular}{|c|c|c|}
\hline No & Negara & Integritas Penyelenggara Pemilihan Umum di beberapa Negara \\
\hline 1 & Afrika Selatan ${ }^{266}$ & $\begin{array}{l}\text { - Sebagai warganegara Afrika Selatan } \\
\text { - } \text { tidak terlibat dalam kepengurusan partai politik. } \\
\text { - Salah satu komisi adalah dari Unsur Hakim }\end{array}$ \\
\hline 2 & Meksiko & $\begin{array}{l}\text { - Warganegara Meksico, dan tidak memiliki kewargenagaraan ganda. } \\
\text { - Memiliki pengetahuan di bidang politik pemilihan umum. } \\
\text { - Memiliki pengalaman menempati jabatan yang setara. Memiliki } \\
\text { reputasi baik dan tidak pernah dihukum karena melakukan kejahatan. } \\
\text { - Tinggal di di wiliayah negara selama } 2 \text { Tahun terakir, kecuali } \\
\text { menjalankan tugas negara selama } 6 \text { bulan. } \\
\text { - Tidak pernah terdaftar sebagai kandidat untuk pemilihan apapun } \\
\text { selama } 5 \text { tahun sebelum ditunjuk. } \\
\text { - Tidak sedang atau pernah memiliki jabatan ketua negara bagian atau } \\
\text { nasional suatu partai politik selama masa } 5 \text { tahun. } \\
\text { - Tidak menjabat sebagai menteri kepala negara bagian atau wakil } \\
\text { menteri. } \\
\text { - Usia minimal } 40 \text { tahun } \\
\text { - Minimal bergelar sarjana } \\
\text { - Bukan merupakan anggota perlemen } \\
\text { - Bukan pejabat atau pejabat daerah } \\
\text { - Tidak pernah memegang jabatan struktur/pemerintahan. } \\
\text { - Bukan anggota Ombudsman, Komisi HAM, Mahkamah Konstitusi, } \\
\text { Komisi anti Korupsi, atau Komisi Pemeriksa Keuangan Negara. } \\
\text { - Ketua dan anggota Komisi pemilu tidak boleh menjabat atau pegawai } \\
\text { istansi pemerintahan, BUMN atau lembaga pemerintahan lokal. }\end{array}$ \\
\hline 3 & Thailand & $\begin{array}{l}\text { - Komite Seleksi terdiri dari wakil partai } \\
\text { - Majelis Rendah } 10 \text { orang terdiri atas Ketua Mahkamah Konstitusi, } \\
\text { - Ketua Pengadilan Administrasi Tinggi, } \\
\text { - Para rektor perguruan tinggi } \\
\text { - } \text { Berkebangsaan Thailand karena Kelahiran. } \\
\text { - Usia minimal } 40 \text { (empat puluh) Tahun } \\
\text { - Komite seleksi memilih } 8 \text { orang untuk diajukan ke Senat. } \\
\text { - Senat setuju, Mahkamah Agung memilih } 5 \text { orang, diajukan ke Senat. }\end{array}$ \\
\hline 4 & Korea Selatan & $\begin{array}{l}\text { - Calon anggota harus merupakan individu yang netral. } \\
\text { - Standar akademik dan etik tinggi (diutamakan Hakim, Pengacara, dan } \\
\text { pengajar. } \\
\text { - }\end{array}$ \\
\hline 5 & Australia & $\begin{array}{l}\text { Australian Electoral Commission (AEC) ada ketentuan hukum mengenai: } \\
\text { - Independensi dan kredibilitas dari penyelenggara pemilihan umum. } \\
\text { - } \quad \text { Adanya kemandirian dalam melaksanakan tugas. } \\
\text { - Tidak ada campur tangan penguasa atau pihak lain. } \\
\text { - } \quad \text { Tidak tereduksi oleh kepentingan politik. } \\
\text { - Berjalan secara terstruktur dan sistematis. } \\
\text { - Pemilu yang transparan dan obyektif. } \\
\text { - Adanya undang undang yang mengatur sistem pemilihan umum } \\
\text { disertai dengan sanksi masing-masing. }\end{array}$ \\
\hline
\end{tabular}

Sumber: Cetro267 diolah pada 9 Agustus 2014

266 Orothai 3Kokpol. 2002. "Politik Pemilu Di Thailand", Dalam Politik Pemilu Di Asia Tenggara Dan Asia Timur. Pensil. Jakarta. Hal : 376-378.

267 Didik Supriayanto. 2007. Menjaga Independensi Penyelenggara Pemilu. USAID. Jakarta. Hal : 29-33 


\section{BAB IX \\ KONSEP PENGAWASAN \\ TERHADAP ANGGOTA \\ PARLEMEN}

\section{A. Konsep Pengawasan Anggota Parlemen}

\section{Pengertian Pengawasan}

Di dalam Kamus Besar Bahasa Indonesia KBBI v1.3276 Kata pengawasan berasal dari kata "awas" berarti memperhatikan dengan baik" Sedangkan pengawasan sendiri berarti penilikan dan penjagaan, penilikan dan pengarahan kebijakan jalannya perusahaan. Pengawasan terdiri atas; Pengawasan melekat yaitu pengawasan yang langsung dilakukan oleh pejabat terhadap bawahannya disetiap tugas yang menjadi tanggung jawab bawahannya itu. Pengawasan preventif yaitu pengawasan terhadap peraturan daerah dan keputusan kepala daerah mengenai pokok tertentu yang baru akan berlaku sesudah ada pengarahan pejabat yang berwenang. Pengawasan represif yaitu penangguhan atau pembatalan peraturan daerah atau keputusan kepala daerah oleh pejabat yang berwenang. Pengawasan umum yaitu pengawasan yang dilakukan oleh pemerintah pusat terhadap segala kegiatan pemerintah daerah.

Pengawasan dari kata dasar "awas" yaitu adanya pihak lain atau pihak diri sendiri dalam suatau organisasi yang memperhatikan dengan baik terhadap

276 Ebta Setiawan, 2012-2014 Kamus Besar Bahasa Indonesia (KBBI) Online dikembangkan oleh Ebta Setiawan Versi 1.3. Badan Pengembangan dan pembinaan bahasa, kemendikbud (pusat) bahasa. Sumber : http://ebsoft.web.id 
yang dikerjakan dengan mengarahkannya sesuai rencana yang telah ditentukan. Di dalam suatu pengawasan dua pihak yang terpenting adalah pihak yang mengawasi yaitu pihak yang diberikan kewenangan baik dari dalam maupun dari luar suatu organisasi (yang diawasi) untuk memperhatikan terhadap pihak yang diawasi dan memberikan pengarahan sesuai ketentuan.

Sedangkan pihak yang diawasi adalah pihak ada hubungannya dengan yang mengawasi, hubungan antara pihak pengawas dan yang diawasi adalah hubungan baik secara kelembagaan atau hubungan karena kompetensi. Dengan demikian bahwa pihak yang mengawasi sesunguhnya memiliki hubungan kelembagaan dan dan mempunyai kompetensi lebih dari pada yang di awasi. Sebab, pihak yang mengawasi akan lebih mampu mengetahui dan memahami lebih jauh terhadap yang diawasi. Sebaliknya, akan tidak berjalan suatu pengawasan dengan efektif, jika pihak pengawas tidak (kompetensi) mengetahui dan atau memahami terhadap pihak yang diawasi, terutama pada pemahaman dari segi kinerja terhadap yang diawasi.

Terkait dengan pengawasan yang pengawasnya memiliki kompetensi dari yang diawasi sebagai landasan Firman Allah SWT dlam al-Qu'ran surah Al Baqarah Ayat 44 yang artinya bahwa:

"Mengapa kamu menyuruh orang lain (mengerjakan) kebajikan, sedangkan kamu melupakan dirimu sendiri, padahal kamu membaca kirab (taurat) tidakkkah kamu mengerti".

Jika Firman Allah SWT. Sebagai turunannya sebagaimana Sabda Rasulullah Muhammad SAW berbunyi "periksalah dirimu sebelum memeriksa orang lain atau lihatlah terlebih dahulu kerjamu sebelum melihat kerja orang lain"

Ayat Al-Quran dan Hadits tersebut jika di kaitkan dengan pengawasan maka penekananya adalah pengawas akan lebih baik (paham) dari yang diawasi, dan lebih membekan suatu pengawasan yang sesungguhnya dia (pengawas) sendiri tidak lalukan yang buruk, demikian pada dia (pengawas) melaksanakan terlebih dahulu suatu apa yang dikerjakan lalu kemudian yang diawasi. Dengan demikian pengawas harus lebih berkompetensi lebih memahami substansi yang diawasi, kehadiran pengawas adalah karena kemampuan bukan semata karen kapabilitas oleh karena suatu syarat yang sebagaimana dikendaki oleh suatu aturan.

Pengawasan tidak mutlak dari luar atau dari dalam suatau organisasi, ketentuannya bahwa pihak yang mengawasi akan lebih memahami dan mengetahui terhadap yang diawasi dengan berdasar pada suatu tujuan yang telah di tentukan. Sehingga, pihak yang di awasi akan senantiasa melaksanakan suatu pekerjaan sebagaimana yang telah ditentukan dengan berdasar pada suatu ketentuan. Ketentuan yang dimaksudkan adalah berupa hukum atau peraturan yang keduanya saling memahami akan tugas pokok, dan fungsinya (tupoksi). Dengan demikian maka dalam suatu pekerjaan akan dapat terencana, terlaksana, dalam mencapai suatu tujuan sebab pengawasan bukan hanya 
pada umumnya mewakili rakyat melalui partai politik. Perwakilan seperti ini bersifat perwakilan politik representatif (political representation).

Jika political representation sebagaimana pandangan Imawan tersebut di atas dimaknai sebagai keterwakilan partai politik. maka, secara "empiris" adalah cukup alasan untuk dibenarkan dengan adanya fakta fakta partai politik merecall anggotanya DPR. Sekalipun, anggota DPR tersebut masih dibutuhkan oleh masyarakat (kostituen).

Berdasar pada pengamatan Imawan menurut hemat penulis bahwa hal tersebut harus diluruskan. Pertama, secara konsep belumlah ada pandagan atau konsep bahwa turunan dari kedaulatan rakyat adalah partai politik atau representatif politik. Kedua, secara politik, tujuan politik adalah untuk kepentingan masyarakat umum, bukan kepentingan partai politik. Ketiga, secara hukum kelemahan dari pada peraturan hukum Indonesia adalah tidak adanya payung hukum yang idel dalam memberikan perlindungan terhadap anggota DPR sebagai mandataris rakyat (konstituen), akibatnya partai politik seolah "menguasai" dari pada anggota DPR, hal tersebut dapat memengaruhi kinerja dalam DPR sebab tentunya akan mengikuti kehendak partai politik, ketimbang keinginan masyarakat.

Sebagai dasar dalam untuk instrument pada sistem pengawasan terhadap anggota DPR, penulis mengacu pada pandangan Muchsan ${ }^{295}$ bahwa: Supaya pelaksanaan pengawasan dapat dijadikan sebagai suatu alat (instrumen) yang efektif maka perlu memperhatikan kriteria-kriteria sebagai berikut:

a. Apa yang akan diawasi (obyek yang perlu diawasi).

b. Mengapa perlu diadakan pengawasan.

c. Dimana dan bilamana diadakan pengawasan dan oleh siapa pengawasan tersebut harus dilakukan.

d. Bagaimana pengawasan tersebut dapat dilakukan.

e. Pengawasan tersebut harus bersifat rasional, fleksibel, terus-menerus dan pragmatis.

Sebagai penjelasan terhadap sistem pengawasan terhadap anggota DPR guna mewujudkan anggota DPR yang aspiratif. Paling tidak ada 3 (tiga) sistem pokok untuk melakukan pengawasan terhadap anggota DPR yaitu; ketentuan lembaga pengawas, substansi yang diawasi, dan bentuk pengawasannya.

\section{Sistem Pengawasan Terhadap Anggota Parlemen di beberapa negara}

Sistem pengawasan terhadap anggota DPR adalah adanya lembaga atau peraturan untuk mengawasi anggota DPR dalam melaksanakan tugas dan fungsinya di parlemen. Sebagai perbandingan pengawasan terhadap anggota DPR dibeberapa negara, dan Indonesia (lihat Tabel VIII).

295 Muchsan, 2000. Sistem Pengawasan Perbuatan Aparat Pemerintah dan Peradilan Tata Usaha Negara, Liberty. Yokyakarta. Hal : 39 
Tabel VIII. Sistem Pengawasan terhadap anggota parlemen dibeberapa Negara

\begin{tabular}{|c|c|c|}
\hline No. & Negara & Sistem pengawasan terhadap anggota parlemen di beberapa Negara \\
\hline 1 & Inggris & $\begin{array}{l}\text { Lembaga: committee on standards in public life dengan gabungan pihak } \\
\text { eksternal dengan komite parlemen. }\end{array}$ \\
\hline 2 & Kanda & $\begin{array}{l}\text { Panduan: Prosedur parlemen } \\
\text { pernyataan: untuk standar perilaku dasar bagi anggota parlemen }\end{array}$ \\
\hline 3 & Ethopia & Peraturan: untuk anggota parlemen \\
\hline 4 & Bahrain & Ikhtisar: memberikan gambaran mengenai lembaga parlemen \\
\hline 5 & Namibia & Panduan mengembangkan sebagai acuan untuk anggota parlemen \\
\hline 6 & Australia & Panduan: mempunyai buku panduan sebagai prosedur parlemen. \\
\hline 7 & India & Panduan: mempunyai buku panduan sebagai prosedur parlemen \\
\hline 8 & Iran & Lembaga Dewan Faqih (Dewan Konstitusi) \\
\hline 9 & Taiwan & $\begin{array}{l}\text { Peraturan: yaitu peraturan pengawasan etika anggota parlemen dilakukan } \\
\text { hanya oleh pihak eksternal. }\end{array}$ \\
\hline 10 & Afrika Selatan & Lembaga: the Ethics Committee adalah lembaga Komite Etik parlemen. \\
\hline 11 & Irlandia & $\begin{array}{l}\text { Pihak eksternal dengan komite parlemen: adalah pelibatan pihak internal } \\
\text { dan eksternal dalam mengontol parlemen. }\end{array}$ \\
\hline
\end{tabular}

Sumber: Data Primer (Edited)

Berdasarkan pada table VIII di atas menggambarkan karakteristik dibeberapa negara, di dalam melakukan pengawasan terhadap anggota parlemen.

Pertama, kelembagaan. bahwa adanya lembaga yang mengawasi sebagaimana pada negara Inggeris yang disebut Committee on Standards Public Life. Keanggotaan pada komite tersebut adalah penggabungan baik pihak eksternal dan komite parlemen. Demikian halnya dengan negara Iran dengan adanya Lembaga Dewan Faqih (Dewan Konstitusi) yang bukan hanya mengawasi anggota Parlemen namun adalah juga mengawasi semua lembaga termasuk eksekutif dan yudikatif. Sedangkan Lembaga pengawas Negara Afrika Selatan disebut the Ethics Committee atau lembaga Komite Etik parlemen. Serta Negara Irlandia dengan adanya pelibatan komite parlemen baik pihak internal dan eksternal dalam melakukan kontrol (pengawasan) terhadap parlemen pada Negara Irlandia.

Kedua, Buku panduan. Terhadap beberapa negara sebagai upaya dalam melakuka pegawasan terhadap anggota Parlemen. Sebagaimana Negara Kanada, Bahrain, Australia, dan India dengan memiliki dan memberikan buku panduan kepada anggota parlemen untuk melaksanakan tugas dan fungsinya di parlemen. Sesungguhnya, hal tersebut sangat efektif sebab lembaga parlemen sebagai lembaga yang anggotanya tidak monoton (dilakuakan pergantian) sesuai dengan periode pada negara masing-masing. Tentunya, adanya anggota 
Sebastian Salang Koordinator Forum Masyarakat Peduli Parlemen disingkat Formappi, pada Tahun 2012 memberikan penilaian dengan cara memanfaatkan data yang dikumpulkan dari sekretariat jenderal DPR dan partai-partai politik. Bahwa berdasarkan berdasarkan laporan yang rilis serangkaian mengenai hasil kerja DPR dengan indikator;

"Kehadiran, persentase kunjungan ke daerah konstituen, dan tingkat transparansi pelaporan harta kekayaan, bahwa Para anggota dewan legislatif tidak terlalu piawai dalam menyelesaikan tugas-tugasnya. Dari sekitar 560 orang anggota DPR, hanya empat yang mendapatkan nilai " $A$ " sementara mayoritas anggota318 orang-dianggap gagal. Penilaian tersebut menunjukkan bahwa tak lebih dari sepertiga anggota menghadiri $85 \%$ sidang DPR. Para anggota yang jarang hadirtingkat kehadiran kurang dari 40\%-mencakup 22\% dari seluruh anggota DPR." 302

Sedangkan, berdasar regulasi DPR, para anggota yang absen dalam enam sidang berturut-turut dapat dipecat. Wakil Ketua Badan Kehormatan DPR, Siswono Yudo Husodo, 303 bahwa beberapa anggota melewatkan sidang empat hingga lima kali berturut-turut. Tapi, mereka muncul pada sidang berikutnya, Dengan begitu, sanksi tidak dapat dijatuhkan. Sekalipun diterapkan namun demikian sejumlah anggota DPR masih dapat menyiasatinya, sehingga tak satu pun anggota DPR yang pernah dipecat karena mangkir dari sidang.

Selain dari pada itu beberapa masalah kinerja yang dilakukan oleh anggota DPR yang dilaporkan oleh Sebastian Salang304 yakni: pertama, di tahun 2012 sekitar 70\% anggota DPR tidak menyambangi daerah pemilihan. Tiap Tahun DPR menangguhkan masa reses tiga bulan untuk melawat daerah konstituen. Sekali dalam masa reses Tahunan DPR tidak memiliki kinerja memuaskan dalam urusan kunjungan ke daerah konstituen.

Kedua, DPR memiliki tugas meloloskan undang undang, mengawasi pemerintah, dan menandatangani proposal anggaran yang diajukan pemerintah. tak satu pun dari tugas-tugas tersebut yang dijalankan secara maksimal.

Ketiga, Tiap Tahun, DPR memasang target meloloskan sejumlah UU. Pada beberapa Tahun belakangan, jumlahnya mencapai 66 hingga 93 UU. Namun, dalam empat Tahun terakhir, DPR hanya mampu memenuhi kurang dari setengah target menghasilkan UU setiap Tahunnya, Tahun 2012, DPR paling banyak meloloskan UU, yakni sekitar 30, Sementara di Tahun 2013, DPR hanya berhasil meloloskan 12 dari 75 target pembuatan UU. Oleh Karena lemanya pengawasan, maka berefek pada tidak berjalannya kinerja anggota DPR.

Hal tersebut menggambarkan bahwa kinerja anggota DPR memang

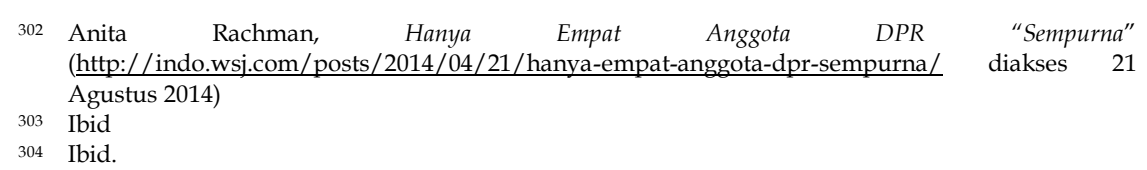


diperlukan adanya pengawasan, sehigga dapat mewujudkan anggota DPR yang aspiratif.

\section{Ketentuan pengawasan terhadap anggota Parlemen di beberapa negara}

Ketentuan pengawasan dimaksudkan adalah muatan yang hendak di awasi terhadap segala aktifitas anggota parlemen. Guna membandingkan ketentuan pengawasan terhadap parlemen di beberapa negara, diuraikan pada Tabel IX di bawah ini:

Tabel IX. Ketentuan pengawasan terhadap anggota parlemen di beberapa negara

\begin{tabular}{|c|c|c|}
\hline No. & Negara & Ketentuan Pengawasan terhadap Parlemen di beberapa Negara \\
\hline 1 & Inggeris & $\begin{array}{ll}\text { - } & \text { Menetapkan kode etik } \\
\text { - } & \text { Tidak mementingkan diri sendiri, } \\
\text { - } & \text { Integritas, } \\
\text { - } & \text { Obyektivitas } \\
\text { - } & \text { Akuntabilitas. } \\
\text { - } & \text { Keterbukaan atas semua keputusan. } \\
\text { - } & \text { Kejujuran } \\
\text { - } & \text { Kepemimpinan }\end{array}$ \\
\hline 2 & Kanada & $\begin{array}{l}\text { - } \quad \text { Mengakui tugas mereka di parlemen. } \\
\text { - } \quad \text { Menjaga kepercayaan publik. } \\
\text { - } \quad \text { Menjaga integritas individu. } \\
\text { - } \quad \text { Meyakinkan masyarakat. } \\
\text { - } \quad \text { Buku panduan prosedur parlemen } \\
\text { - } \quad \text { Panduan debat } \\
\text { - } \quad \text { Panduan pertanyaan kepada menteri } \\
\text { - } \quad \text { Instrument undang-undang, } \\
\text { - } \quad \text { Urutan peraturan dan urutan program. } \\
\text { - } \quad \text { Tidak memihak }\end{array}$ \\
\hline 3 & Uganda & $\begin{array}{l}\text { - Prinsip dasarnya tidak; mementingkan diri sendiri, integritas, } \\
\text { obyektivitas, akuntabel, keterbukaan, kejujuran dan mendorong } \\
\text { tata kelola pemerintahan yang baik. }\end{array}$ \\
\hline 4 & Ethopia & $\begin{array}{l}\text { - Pelayan masyarakat. } \\
\text { - } \quad \text { Loyal } \\
\text { - Jujur } \\
\text { - } \quad \text { Menjadi contoh bagi warga ethiopia, } \\
\text { - } \quad \text { Menghormati masyarakat \& nasional } \\
\text { - } \quad \text { Menjaga martabat dan kehormatan parlemen" }\end{array}$ \\
\hline 5 & Australia & $\begin{array}{l}\text { - } \quad \text { Pengawasan yang menggunakan kantor publik } \\
\text { - } \quad \text { Pengawasan penggunaan dana publik; } \\
\text { - } \quad \text { Panduan prosedur parlemen yang lebih detail } \\
\text { - Panduan lembaga berjalan. } \\
\text { - } \quad \text { Panduan debat } \\
\text { - Panduan pertanyaan kepada menteri, } \\
\text { - } \quad \text { Aspek teknis mengenai instrument undang-undang, urutan } \\
\quad \text { peraturan dan urutan program. }\end{array}$ \\
\hline
\end{tabular}




\begin{tabular}{|c|c|c|}
\hline 6 & Bahrain & $\begin{array}{ll}\text { - } & \text { Menempatkan diri atas konflik kepentingan; } \\
\text { - } & \text { Tidak menggunakan kantor untuk pribadi; } \\
\text { - } & \text { Tidak Merendahkan martabat institusi } \\
\text { - } & \text { Mempertaruhkan integritas; } \\
\text { - } & \text { Tidak melemahkan integritas pemerintah. }\end{array}$ \\
\hline 7 & Nabibia & $\begin{array}{l}\text { - Melengkapi aturan prosedur } \\
\text { - Menerangkan mengenai lembaga dan proses yang terjadi di } \\
\text { dalamnya }\end{array}$ \\
\hline 8 & India & $\begin{array}{l}\text { - } \quad \text { Mempunyai panduan prosedur parlemen } \\
\text { - } \quad \text { Termasuk panduan lembaga tersebut berjalan. } \\
\text { - } \quad \text { Panduan pendek debat }\end{array}$ \\
\hline 9 & Iran & $\begin{array}{l}\text { - } \quad \text { Dewan Faqih (Majelis Pengawas Konstitusi) } \\
\text { - } \quad \text { Mengawasi jalannya pemerintahan, } \\
\text { - } \quad \text { Mengawasi semua institusi yang berhubungan dengannya. }\end{array}$ \\
\hline 10 & Taiwan & $\begin{array}{l}\text { - Pengawasan etika hanya oleh pihak eksternal. } \\
\text { - } \quad \text { Melibatkan badan yudisial atau kuasi-yudisial }\end{array}$ \\
\hline 11 & Afrika Selatan & - Melakukan penyidikan sendiri terhadap anggota parlemen. \\
\hline 12 & Irlandia & - $\quad$ Melakukan pengawasan dan memberikan sanksi. \\
\hline 13 & Chile & $\begin{array}{l}\text { - Menggunakan jabatan untuk keuntungan pribadi. } \\
\text { - } \text { - Mendapatkan keuntungan untuk mempengaruhi tindakan pejabat. } \\
\text { - } \quad \text { Menerima hadiah dari pejabat atau pegawai melebihi nilai tertentu. } \\
\text { - } \\
\text { - } \\
\text { - Menerima honor dari pejabat publik. } \\
\text { - Melakukan nepotisme. } \\
\text { Melakukan pekerjaan bisnis di luar parlemen dengan } \\
\text { - } \quad \text { Menggunakan jabatannya. }\end{array}$ \\
\hline
\end{tabular}

Sebagaimana Table IX di atas menggambarkan ketentuan pengawasan dibeberapa Negara, memiliki beberapa perbedaan dan persamaan mengenai substansi atau aspek yang diawasi tertuang dalam peraturan, dengan adanya buku panduan, sebagaimana diuraikan berikut di bawah ini:

Pertama, sebagaimana di Negara Inggeris ketentuan pengawasan terhadap anggota parlemen adalah menetapkan adanya kode etik baru yang komprehensif untuk anggota perleman materi kode etik paling tidak memuat, yakni:

1) Anggota parlemen tidak mementingkan diri sendiri, namun seharusnya bertindak untuk kepentingan masyarakat, tidak boleh memperoleh keuntungan financial atau keuntungan lain untuk diri mereka, keluarga, atau teman-teman mereka.

2) Integritas, dalam menjalankan pekerjaan publik, termasuk membuat penetapan, memberikan kontrak, atau merekomendasikan individu untuk penghargaan dan keuntungan, pemegang jabatan publik harus mempertimbangkan dasar kepantasan.

3) Obyektivitas, yaitu: menjalankan pekerjaan publik, termasuk membuat penetapan, memberikan kontrak, atau merekomendasikan individu 


\section{INDEKS}

A

Akuntabilitas

Anggaran Dasar

Anglo Saxon

ART

B

Badan Kehormatan

C

Calon

Chaldean

Camara dos deputados of Brazil

Chamber of deputies Italy

Congreso nacional de Chile

D

Demokrasi

Deutscher bundestag German

Dewan Perwakilan Rakyat

E

Eksekutif

F

Figur

Fungsi Parpol

H

HAM

House of representatives

\section{I}

Indikator demokrasi

Integritas

Islam

J

Judgement

Jurdil
K

Kedaulatan

Kekuasaan

Kelompok

Ketentuan hukum

Keterwakilan Perempuan

Keterwakilan rakyat

Ketuhanan

Kinerja

Kode Etik

Konstitusi

Kontrak sosial

KPU

M

Mandat

Mandat bebas

Mandat imperatif

Mandat representatif

Mekanisme

Model delegate

Model diverifikasi

Model kesatuan

Model Political

Model trustee

MPR

$\mathbf{N}$

Negara hukum

Nomokrasi Islam

P

Pancasila

Parlemen

Partai politik

Pemilihan umum

Pemilu internasional

Pengawasan

Penyelenggaran

Peradilan

Perwakilan anticipatory 
Perwakilan deskriptif perwakilan deskriptif Perwakilan formal Perwakilan fungsional Perwakilan gyroscopic Perwakilan promissory Perwakilan rakyat Perwakilan representatif Perwakilan simbolik Perwakilan substantif Perwakilan Surrogate Politik uang

Popularitas

Profesionalitas

$\mathbf{R}$

Raja

Rechtstaat

Rectum

Rekrutmen

\section{$\operatorname{Rex}$}

S

Sistem pemilihan umum

Sistem pengawasan

Socialist legality

Supremacy of law

T

Teokrasi

The islamic consultative assembly of iran

The legislature may singapore

The national legislative assembly thailan

The rule of law

W

Wakil adat

Wakil agama 


\title{
GLOSARIUM
}

\begin{abstract}
Akuntabilitas
Kewajiban dari institusi pemerintahan maupun aparat yang bekerja di dalamnya untuk membuat kebijakan maupun melakukan aksi yang sesuai dengan nilai yang berlaku maupun kebutuhan masyarakat.
\end{abstract}

\section{Demokrasi}

Sistem pemerintahan dalam suatu negara di mana semua warga negara memiliki hak, kewajiban, kedudukan dan kekuasaan yang baik dalam menjalankan kehidupannya maupun dalam partisipasi dalam kekuasaan negara, warganegara berhak ikut serta menjalankan negara atau mengawasi jalannya kekuasan negara.

\section{Dewan Perwakilan Rakyat}

salah satu lembaga tinggi negara dalam sistem ketatanegaraan Indonesia yang merupakan lembaga perwakilan rakyat.

\section{Rechtstaat}

Adanya berkepastian hukum terhadap seluruh warganegara, yang dikelola oleh warga yang berdaulat melalui pemerintahan dalam memberikan pelayanan kepada masyarakat untuk kepentingan umum.

\section{Hukum}

Aturan hukum adanya perintah, larangan, dan kebolehan dalam suata negara yang dibuat, dilaksanakan, dan di tegakkan oleh lembaga yang berweweang dalam suatu negara.

\section{Islam}

Adalah suatu agama (ad-din) oleh Allah SWT yang petunjuknya melalui dalam Al-qur,an dan hadits untuk keselamatan manusia baik dunia dunia maupun akhirat.

\section{Integritas}

Segala sesuatu yang melekat pada diri (individu), yang dapat melaksanakan tugasnya sebagaimana ketentuan hukum yang berlaku.

\section{Negara}

Oganisasi dalam suatu wilayah yang mempunyai kekuasaan tertinggi yang sah dan ditaati oleh rakyat.

\section{Negara Hukum}

negara hukum atau negara berdasarkan atas hukum (rechtstaat atau the rule of law), yang mengandung prinsip-prinsip asas legalitas, asas pemisahan (pembagian) kekuasaan, dan asas kekuasaan kehakiman yang merdeka, semuanya itu bertujuan untuk mengendalikan negara atau pemerintah dari kemungkinan bertindak sewenang-wenang atau penyalahgunaan kekuasaan. 


\section{Pengawasan}

Suatu tindakan pengawasan mulai dari perencanaan, proses hingga capaian (tujuan) yang diberikan kepada pihak yang berwewenang untuk menginterpretasikan fakta fakta (kejaidna) dengan berdasar pada ketentuan hukum baik tertulis maupun secara tidak tertulis.

\section{Parlemen}

orang-orang yang duduk dalam parlemen yang bertugas untuk menyuarakan kehendak, keinginan, dan melakukan pengawasan terhadap eksekutif untuk tujuan kepentingan rakyat dalam kehidupan bernegara.

\section{Profesionalitas}

Suatu sikap mental yang dimiliki oleh seseorang yang mempunyai kemampuan teknis, kemampuan teori, rasa tanggung jawab dan rasa kesejawatan.

\section{Perwakilan}

Orang atau kelompok orang yang mewakili orang lain.

\section{Pemilihan Umum}

Proses pemilihan umum melalui partai politik sehingga orang-orang yang hendak dipilih adalah orang yang ditentukan/verifikasi oleh partai politik untuk diserahkan kepada rakyat untuk dipilih.

\section{Partai Politik}

Suatu organisasi perkaderan yang bertujuan merebut kekuasaan, berdasarkan visi misi dan melalui pelibataan seluruh kelompok masyarakat yang tergabung di dalamnya.

\section{Representatif}

Sistem demokrasi yang dibangun tetap dilakukan melalui sistem perwakilan merupakan cara terbaik untuk membentuk "representative government".

\section{Rekrutmen}

Adalah suatu penetapan pengurus partai politik sesuai AD/ART partai politik, yang berdasarkan pada aturan hukum yang berlaku.

Kinerja

Hasil kerja yang dicapai oleh seseorang karyawan dalam melaksanakan tugas yang dibebankan kepadanya.

\section{Mekanisme}

Cara kerja suatu organisasi untuk mencapai suatau tujuan sebagaimana di tentukan dalam aturan organisasi.

\section{Kedaulatan}

Konsep megenai kekuasaan tertinggi dalam suatu negara, dalam hal siapa yang berdaulat maka dikenal lima teori atau ajaran yang dikenal dalam ilmu hukum, yaitu: teori kedaulatan Tuhan, teori kedaulatan Raja, teori kedaulatan negara dan teori kedaulatan rakyat. 
SEBUAH harapan bahwa anggota partail politik yang yang di rekrut untuk duduk di parlemen adalah dapat melaksanakan fungsi legislasi, budgeting dan pengawasan. Buku di tangan pembaca ini mengupas beberapa aspek kajian perbandingan, yakni: Pertama, bahwa anggota parpol dalam mengikuti tahapan seleksi di partal politik melalui mekanisme, syarat serta adanya proses penguatan anggota parlemen oleh partai politik sebagai peserta pemilihan umum; Kedua, adanya penyelenggara pemilihan umum yang professional, akuntabilitas; dan Ketiga; anggota DPR yang terpilih melalui mekanisme dengan syarat dan ketentuan yang diatur, maka anggota DPR harus diawasi oleh suatu lembaga tertentu, terhadap baik kinerja, etika selama menjadi anggota DPR bentuk pengawasannya baik secara preventif maupun secara represif. Hal itu semua dif atura dalam ketentuan hukum yang berlaku.

Pada kajian buku ini mengkaji aspek kelembagaan partai politik dalam melakukan rekrutmen politik, kelembagan penyelenggara pemilihan umum dalam menyelenggarakan pemilihan umum, dan bentuk pengawasan terhadap anggota lembaga parlemen. Dengan melakukan pendekatan comparative aproach, yaitu melakukan perbandingan dengan beberapa konstitusi hingga peraturan perundang-undangan serta praktik yang dilaksanakan di beberapa negara.

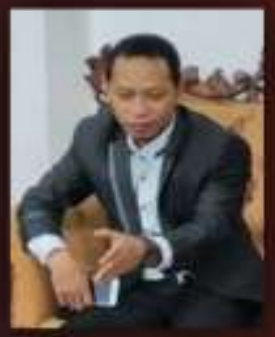

\section{Penulis:}

Br. Patawari, S.HI., M.H.

Lahir podo 15 Mei 1981 di Eanrego, Kabupaten Bane Sulawest Selaten Profesi dosen tetap Fakultas Hukum Uir Makasaan dan dosen tamu di beberapa parpuruen Einggi di kawaean timur Indconeata, dan ektef sebagai Koneulten Hukum Perancangan Peraturan Perundang Lixtorgan

Es UIN Alaudin Makassar Se Hukum Tata Nepara Unhas ga limu Hukum UNHAS dan pexnah ekt it HML. KNPI, KEPMl EQNE den

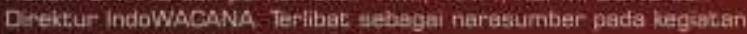
ilminh dan medis TV Lekal di Mpkasar. 